
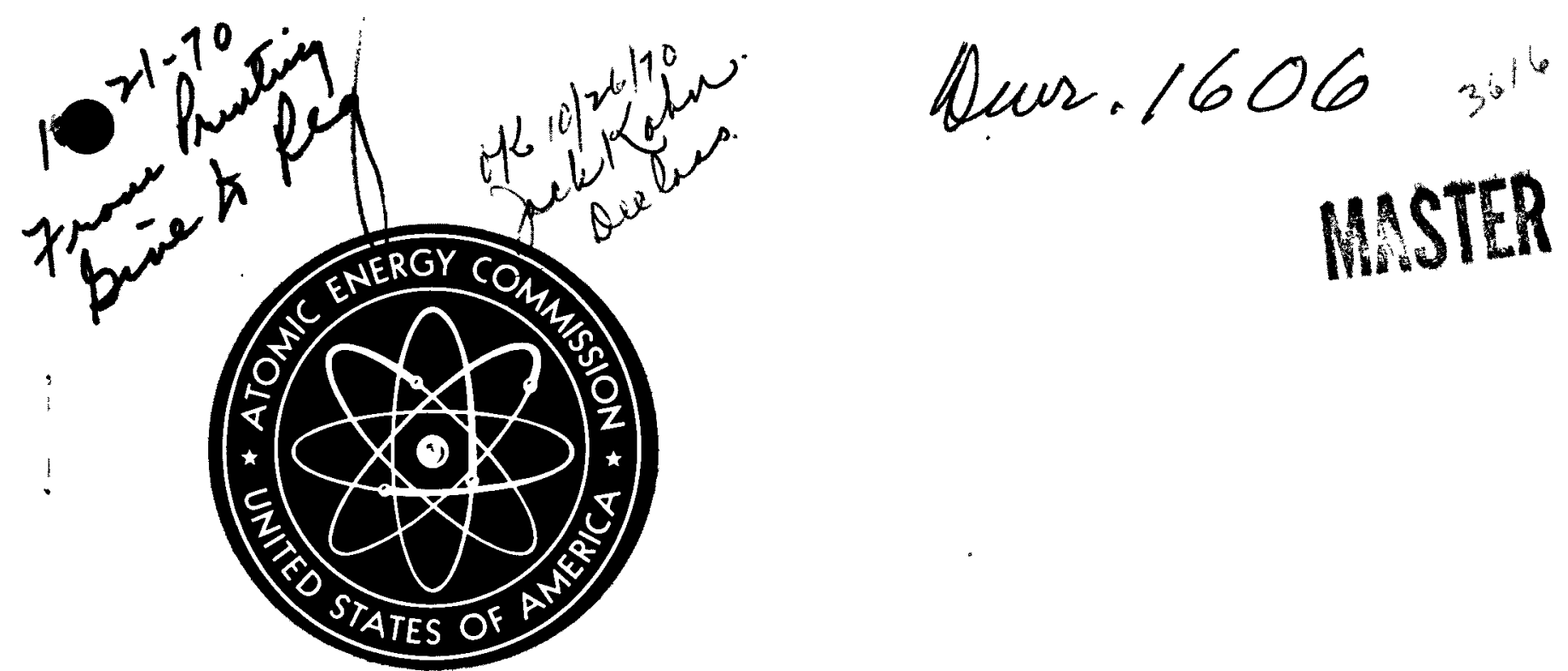

WASH-1152

AEC CONCEPTUAL HIGH-TEMPERATURE GAS-COOLED REACTOR (HTGR) FUEL PROCESSING PLANT

October 1970

Idaho Nuclear Corporation Idaho Falls, Idaho

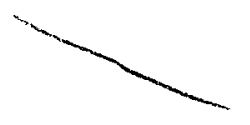




\section{DISCLAIMER}

This report was prepared as an account of work sponsored by an agency of the United States Government. Neither the United States Government nor any agency Thereof, nor any of their employees, makes any warranty, express or implied, or assumes any legal liability or responsibility for the accuracy, completeness, or usefulness of any information, apparatus, product, or process disclosed, or represents that its use would not infringe privately owned rights. Reference herein to any specific commercial product, process, or service by trade name, trademark, manufacturer, or otherwise does not necessarily constitute or imply its endorsement, recommendation, or favoring by the United States Government or any agency thereof. The views and opinions of authors expressed herein do not necessarily state or reflect those of the United States Government or any agency thereof. 


\section{DISCLAIMER}

Portions of this document may be illegible in electronic image products. Images are produced from the best available original document. 


\section{LEGAL NOTICE}

This report was prepared as an account of work sponsored by the United States Government. Neither the United States nor the United States Atomic Energy Commission, nor any of their employees, nor any of their contractors, subcontractors, or their employees, makes any warranty, express or implied, or assumes any legal liability or responsibility for the accuracy, completeness or usefulness of any information, apparatus, product or process disclosed, or represents that its use would not infringe privately owned rights.

This report has been reproduced directly from the best available copy.

Printed in USA. Price $\$ 3.00$. Available from the National Technical Information Service, U. S. Department of Commerce, Springfield, Virginia 22151. 


\section{RRRATA TO WASH-1152}

The equation appearing on page 28 which reads:

$D_{a}=\$ 104,000 \mathrm{M}+\$ 26,000 \mathrm{~N}$

Should read:

$$
D_{a}=\$ 104,000 M+\$ 26,000 N+\$ 130,000
$$




\title{
AEC CONCEPTUAL HIGH-TEMPERATURE GAS-COOLED REACTOR (HTGR) FUEL PROCESSING PLANT
}

\author{
PREPARED BY \\ IDAHO NUCLEAR GORPORATION \\ UNDER THE DIRECTION OF \\ DIVISION OF PRODUCTION \\ UNITED STATES ATOMIC ENERGY COMMISSION
}

\section{LEGAL NOTICE}

This report was prepared as an account of work This report was prepared States Government. Neither sponsored by the United States Gover Atomic Energy the United States nor the United States Atomic Energy Commission, nor any of their employees, nor any of their contractors, subcontractors, or their employees, makes any warranty, express or implied, or assumes anylegal liability or responsibility for the accuracy, completeness or usefulness of any information, apparatus,

product or process disclosed, or represents 


\section{ABSTRACT}

This report describes the technical background and economic and process parameters used to develop a single purpose conceptual plant for processing irradiated High-Temperature Gas-Cooled Reactor (HTGR) fuel. Information on the plant design criteria, plant capital cost, operating cost estimate, etc, is also provided. 


\section{SUMMARY}

Facility and process descriptions are given for a conceptual processing plant capable of processing graphite-based HTGR fuel. The single-purpose plant is designed to process annually 260 tonnes (metric tons) of heavy metals from HTGR reference fuel. The design incorporates a burn-leach type headend, a modified Acid-Thorex solvent extraction system for recovery of heavy metals from fertile particles, and a denitration system for the U-233. The fissile particles are packaged and placed in retrievable storage. Extended storage of thorium as a nitrate solution is assumed, and radioactive waste solutions are stored for up to two years before conversion to granular solids in a fluidizedbed calciner. These solids are stored (permitting retrieval) on-site for four years prior to being canned and shipped to a Federal Repository for final storage along with the fissile particles.

An independent architect-engineering firm, Bechtel Corporation, prepared the design and capital cost estimate for plant construction and equipment; Idaho Nuclear Corporation estimated the operating costs and those capital costs primarily associated with owner's costs and not estimated by Bechtel[a]. Capital and operating costs for the conceptual plant are incorporated into a present worth evaluation to determine a daily processing charge for the plant. The basic processing complex is estimated to have an initial capital cost of about 70.6 million dollars and an annual operating cost of 8.79 million dollars. An additional 11.4 million dollars for capital equipment is required for supplemental facilities after startup.

[a] A detailed breakdown of the capital costs is given in Appendix C. 
ABSTRACT. ................... ii

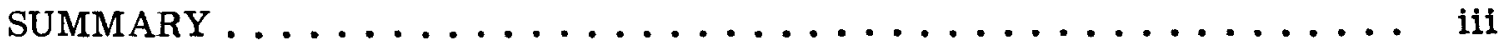

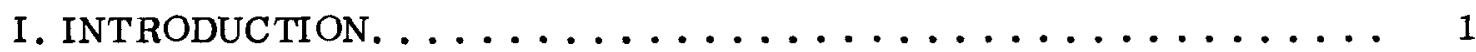

II. BRIEF DESCRIPTION OF PROCESS .............. 4

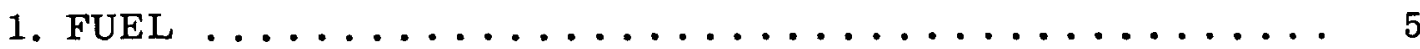

2. PROCESS FLOWSHEET. ................ 5

III. ECONOMICS ........................ 9

1. CAPITAL COST ESTIMATES . . . . . . . . . . . . . 9

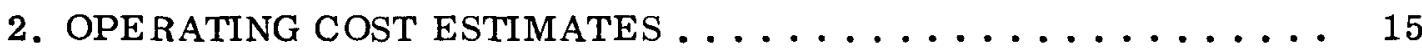

3. METHOD OF DETERMINING THE BATCH PROCESSING

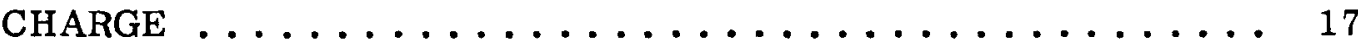

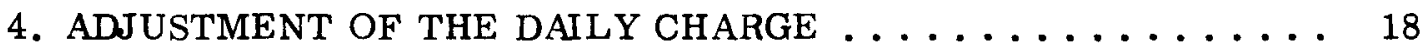

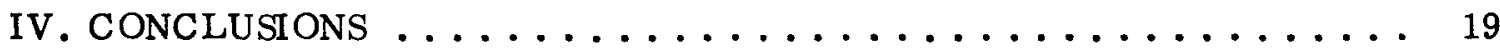

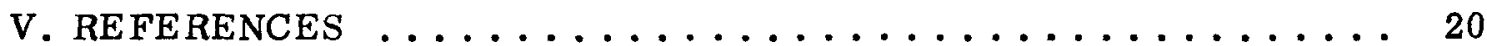

APPENDIX A -- DESCRIPTION OF PROCESS AND FACILITY . . . . . 23

APPENDIX B -- ECONOMIC MODEL AND ASSUMPTIONS . . . . . . . . 43

APPENDIX C -- CONCEPTUAL PLANT CAPITAL COSTS . . . . . . . . 49

APPENDIX D -- ESTIMATED MANPOWER AND SALARY REQUI REMENTS FOR STAFFING THE CONCEPTUAL PLANT . . . . . 55

APPENDIX E -- ESTIMATED CHEMICAL REQUIREMENTS FOR THE CONCEPTUAL PLANT . ............ 61

APPENDIX F -- ESTIMATED SOLID WASTE DISPOSAL COSTS . . . . 65

\section{FIGURES}

1. Simplified block flow process diagram . . . . . . . . . 7

2. Project schedule ....................... 13

3. Capital expenditure distribution $\ldots \ldots \ldots \ldots \ldots \ldots \ldots \ldots$

A-1. Simplified flowsheet for HTGR reference fuel $\ldots \ldots \ldots \ldots 26$

A-2. General plant layout . . . . . . . . . . . . . . . 37

A-3. Process area layout . . . . . . . . . . . . . . . . . 41

A-4. Process equipment layout $\ldots \ldots \ldots \ldots \ldots \ldots \ldots \ldots \ldots \ldots \ldots$ 


\section{TABLES}

I. HTGR Reference Fuel Description . . . . . . . . . . 6

II. Capital Cost Summary for the Conceptual Plant . . . . . . . . . . 10

III. Conceptual Plant Operating Cost Summary . . . . . . . . . . . 16

B. Present Worth Analysis -- Daily Rate Basis . . . . . . . . . 47

C. Conceptual Plant Capital Costs . . . . . . . . . . . . . . 52

D. Conceptual Plant Personnel . . . . . . . . . . . . . 58

E. Chemical Requirements of the Conceptual Plant .........663

F. Annual Solid Waste Disposal Costs . . . . . . . . . . . 67 


\section{AEC CONCEPTUAL HIGH-TEMPERATURE GAS-COOLED REACTOR (HTGR) FUEL PROCESSING PLANT}

\section{INTRODUCTION}

The AEC policy for receiving and making financial settlement for spent fuels as announced in the Federal Register in March 1957 and superceded by $33 F_{30}{ }^{[1]}$ on January 3,1968 , allows a commercial reactor operator to deliver spent fuel elements to the AEC for financial settlement if commerctal processing services are not available at reasonable terms and prices. The financial settlement involves charges for processing (based on cost data for a reference processing plant), and credits for the contained nuclear material in the spent fuel. Since the reference processing plant does not have the capability to process HTGR fuels, cost data were needed for a conceptual plant, with this capability, to develop a processing charge for these fuels.

A modified thorium fuel cycle ${ }^{[2]}$ is planned for those HTGR fuels that would be handled in the conceptual plant. In this fuel cycle, fertile fuel particles containing primarily Th-232 are used for conversion to U-233. The U-233 in turn sustains criticality as the U-235 is depleted from the fissile fuel particles. Eventually, when enough U-233 has been generated in the reactors and reclaimed, U-233 may be substituted for some or all of the U-235 in the fissile particles. Initially, however, both $\mathrm{U}-233$ and $\mathrm{U}-235$ are in the fuel, and they must be separated to prevent the U-233 in fertile particles from becoming unnecessarily contaminated with U-234, U-235, and significant quantities of U-236 from the fissile particles. Current thinking is that the fissile particles should not be processed, but should be stored because the desirability of recycling this material to a reactor is highly questionable.

The development of cost data for HTGR fuels involved the preparation of (a) design criteria for a single-purpose, self-contained plant, (b) a conceptual plant design, (c) a capital cost estimate, (d) an operating cost estimate, and (e) an economic analysis of all cost data to establish a daily charge for operating the conceptual plant. The conceptual plant was designed as a singlepurpose, self-contained, commercial plant capable of processing 260 tonnes of heavy metals ( $T h+U$ ) annually (HTGR reference fuel). In addition, the uranium 
product was to be shipped to its owner as a canned bulk oxide, and all radioactive wastes were to be shipped as a solid to a Federal Repository for longterm storage or disposal.

Design criteria were prepared by Idaho Nuclear Corporation. All necessary assumptions and bases were defined, and the type of fuel to be processed and conceptual flowsheets were described in the design criterila. In addition, design criteria for the site, process equipment, buildings, and services were prepared.

Based on these design criteria, conceptual design and capital cost estimates were prepared using the following as a general basis:

Plant Owner:

Plant Location:

Construction Wage Rates:

Engineering Constructor

Scope and Responsibilities:

Accuracy of Estimate:
A private concern.

Assumed to be similar to that of the National Reactor Testing Station (NRTS), Idaho.

The estimate was based on construction wage rates for a near average U.S. area, Denver, Colorado.

Complete installation, including detailed engineering, procurement, construction, and mechanical checkout, of a spent fuel processing plant for HTGR-type fuel.

All costs were as of July 1969. Assuming that the specified process and equipment were satisfactory, neglecting es calation costs, but including contingency, the accuracy of the estimate was expected to be within 20 percent of the cost of the plant described. Assuming no escalation of costs over the design and construction period was a simplification and would result in a lower cost than would be anticipated for an actual plant.

Considerable effort was expended in this study to take advantage of all available information relative to the HTGR fuel cycle. All processes and flowsheets used in the study are based on information gathered at Oak Ridge National. Laboratory (ORNL), on published work from ORNL, Gulf General Atomic (GGA), and others, and on development and operational experience at the Idaho Chemical Processing Plant (ICPP). An independent architect-engineering 
firm (Bechtel Corporation) performed the design and cost estimate for the conceptual plant. 


\section{BRIEF DESCRIPTION OF PROCESS}

Process, plant, and equipment designs for the Conceptual HTGR Fuel Processing Plant in this study are based on proven technology whenever possible; in a few cases, the design is based on available research, and some additional development in these areas is desirable. Totally unproven schemes are not considered since capital costs for such schemes are highly speculative. There are, of course, some alternative possiblities that could be used in place of the facilities assumed for the conceptual plant in this study. However, the alternative possibilities are in varying stages of development and none have been completely demonstrated. The crush-burn-grind-leach process ${ }^{[3,4,5]}$ assumed for this study is the best developed of the alternative headend processes. Likewise, the fluidized-bed waste calcination process ${ }^{[6]}$ is the best developed waste disposal method. Consequently, these processes are designated for use in the conceptual plant. Although the plant is designed primarily for processing the HTGR reference and Fort St. Vrain fuels, it is also capable of processing Peach Bottom I fuel, and probably other future HTGR-type fuels.

The design capacity of the process is 260 tonnes per year of heavy metals (after burnup) from HTGR reference fuel. Irradiated fuel is cooled 210 days prior to processing to allow essentially all Pa-233 to decay to U-233. With this cooling time, radioiodine decays to a negligible level.

The U-233 product is shipped in the form of $\mathrm{UO}_{3}$ as a free flowing powder and essentially free from thorium contamination. The metallic and other specified impurities meet AEC specifications ${ }^{[7]}$.

Since the fissile material from any high-burnup HTGR fuels contains large quantities of U-234 and U-236, the desirability of recycling this material to a power reactor is highly questionable. Therefore, the fissile particles are packaged in high-integrity stainless steel containers, stored in a water-filled canal for a period of four years, and then shipped to a Federal Repository for ultimate disposal.

Because of the presence of Th-228 from the decay of $\mathrm{U}-232$, thorium recovered from irradiated HTGR fuel elements has a significantly higher radiation level than naturally occurring thorium. Cost of reactor-grade thorium is low enough that immediate reuse of irradiated thorium probably is not justified. 
After 15 years of storage, however, the Th-228 and daughters decay to levels comparable to that of natural thorium ${ }^{[8]}$ at which time the thorium could be processed through extraction facilities to separate all radioactive daughter components. Therefore, thorium solution is stored as a second cycle raffinate (after reduction in volume by evaporation) in large underground tanks for eventual reuse.

\section{FUEL}

The reference fuel described in Table I is the type originally intended for use in future HTGR's including the Fort St. Vrain reactor ${ }^{[9]}$. This fuel consists of two types of fuel particles bonded in graphite blocks. The particles (fertile and fissile) have consecutive coatings of buffer carbon, silicon carbide (SiC), and pyrolytic carbon. However, it is recognized that other types of fuel, such as the Peach Bottom I type, could be employed; these could be handled by modifying the process slightly with little or nochange in capital costs.

If recycled U-233 is used to replace the U-235 in the fissile particles during fuel fabrication, the process could still be used to handle the fuel, regardless of (a) the particle type, (b) the desire to process the fissile particles, or (c) whether or not the fertile-particle U-233 is to be kept separate from the fissile-particle U-233.

\section{PROCESS FLOWSHEET}

The flowsheet chosen for processing the graphite-matrix HTGR fuel employs a crush-burn-grind-leach type headend, a modified Acid-Thorex solvent extraction system ${ }^{[10,11]}$, and a denitration system for the recovered U-233. Engineering and economics were the primary considerations in all flowsheet design and equipment selections. A block flow diagram of the conceptual plant process is given in Figure 1.

In the process chosen, fertile particles are processed to separ st thorium and fission products from the bred U-233, and the fissile particles are stored for an interim period to permit fission product decay prior to burial. As received, 


\begin{tabular}{ll}
\hline Length (in.) & 31.22 \\
Width (in.) & $14.17\left(\begin{array}{c}\text { across flats of hex. } \\
\text { block) }\end{array}\right.$
\end{tabular}

Unirradiated Fuel

Type

Thorium (fertile particles)

Uranium (fissile particles)

Weight

(kg/element)

11.19

0.57

Total Heavy Metal Content 11.76

Irradiated Fuel

\section{Fertile Particles}

Tho kernel

With buffer carbon coating

With SiC intermediate coating

With pyrolytic carbon coating

Thorium

Uranium ( 83 percent U-233)

Fission products

Oxygen (oxides)

SiC coating

Pyrolytic carbon and buffer carbon coatings
Weight at Discharge (kg/element)
10.48

0.30

0.41

1.55

0.87

10.90

Total 24.51

\section{Fissile Particles}

$\mathrm{UO}_{2}$ kernel

With buffer carbon coating

With SiC intermediate coating

With pyrolytic carbon outer coating

Uranium (primarily U-234 and U-236)

Fission products

Oxygen (oxides)

Buffer carbon

Silicon carbide

Pyrolytic carbon
200

260

280

400
0.15

0.42

0.08

0.30

0.36

$\underline{2.22}$

Total 3.53

Boron carbide

Graphite fuel block

Carbon binder

Total Weight of Fuel at Discharge 130.59

Minimum cooling time (days)

Average burnup (MWd/tonne of heavy metals) 68,000 


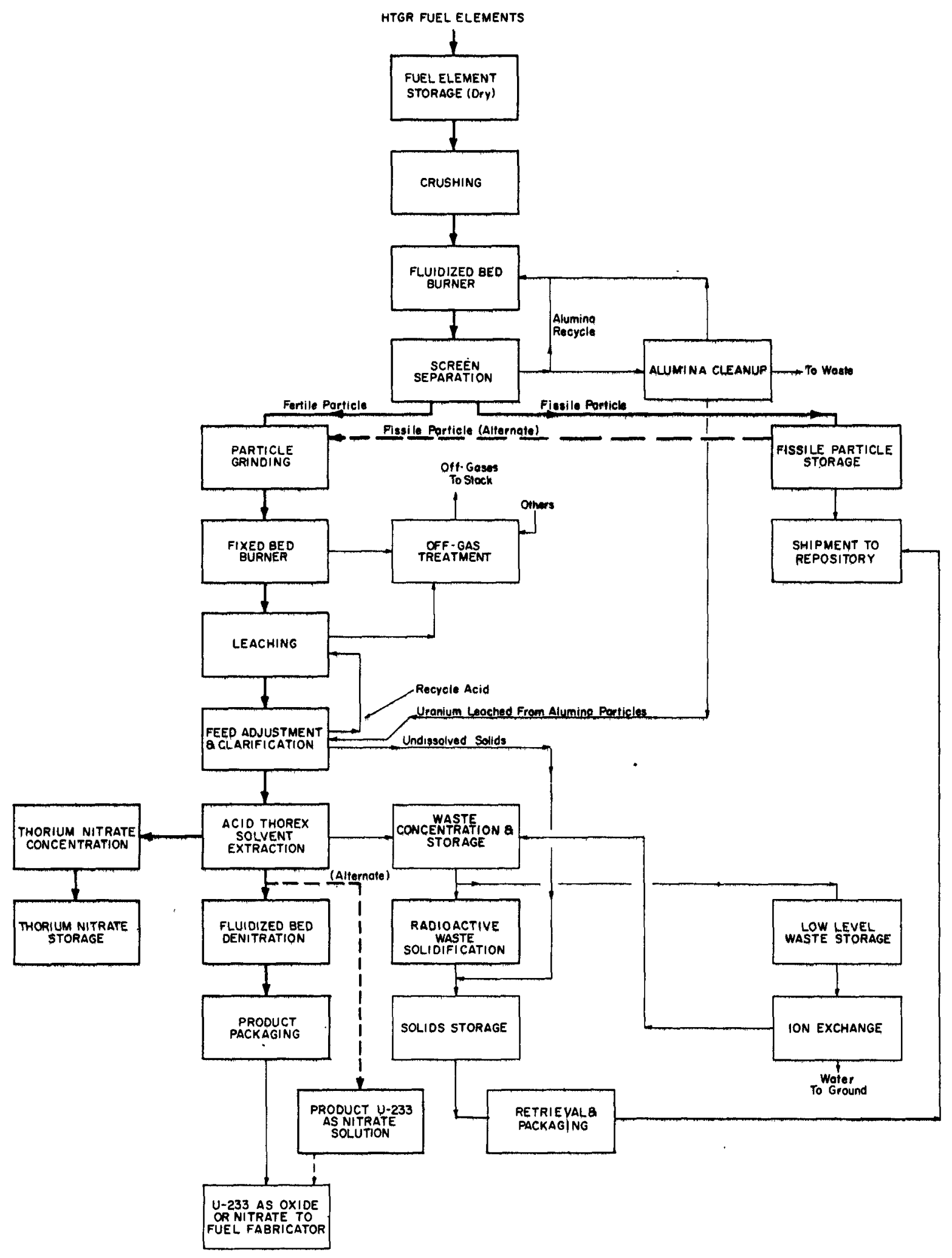

FIG. I SIMPLIFIED BLOCK FLOW PROCESS DIAGRAM. 
HTGR fuel elements are placed in reusable containers and stored in a dry vault. Storage containers are used to minimize contamination of the storage area, and of the cooling and ventilation air.

Preparation of fuel for processing starts with transferral of elements to the crushing cell. Reference-type fuel is added remotely to crushers where the fuel elements are mechanically reduced in size to pieces less than one inch in diameter to (a) assure a more continuous (rather than intermittent) feed to the burner and (b) to promote efficient burner operation by providing a larger surface area for combustion of the graphite.

The crushed fuel elements are burned in a continuous fluidized bed of inert alumina particles to separate $\mathrm{SiC}$-coated fertile and fissile particles from the bulk graphite. The combustion process, conducted in the temperature range of 1300 to $1400^{\circ} \mathrm{F}$ using varying concentrations of oxygen, allows the SiCcoated fuel kernels to remain intact [12]. The fissile and fertile particles are separated by screening. The fissile particles are stored; the fertile particles are crushed and fed to a fixed bed burner. The ash from the burner is leached and the leachate fed to a three-cycle solvent extraction system.

To minimize solvent degradation, the first extraction cycle utilizes a six-stage centrifugal contactor similar in design to those developed at the Savannah River Plant $[13,14,15]$. Pulsed columns similar to those used in most of the existing nuclear fuel processing plants are used for the remaining solvent extraction, scrubbing, and stripping processes. Separate solvent treatment systems, one for the 30 percent TBP and one for the 5 percent TBP, are used to remove fission and TBP decomposition products from the organic solvent.

The uranium product is concentrated, denitrated in a fluidized bed denitrator, and packaged for shipping. A more detailed process and facility description is given in Appendix A. 


\section{ECONOMICS}

The basis for all cost estimates used in this study was that the processing plant would be built and operated by private industry; therefore, all costs (excluding taxes ${ }^{[a]}$ ) normally encountered by private enterprise are incorporated into the economic analysis. A cash-flow procedure was employed and allowance for the time value of money was made by using a present worth evaluation. A daily plant operating charge of $\$ 130,000 /$ day was calculated for the HTGR conceptual plant. The economic model and the basic economic and operating parameters used in the study are provided in Appendix B.

\section{CAPITAL COST ESTIMATES}

The construction capital cost estimate for the Conceptual HTGR Fuel Processing Plant was prepared by Bechtel Corporation using procedures for the most part which are routine with modern engineering-construction firms. However, any cost escalation that might occur during construction is omitted, and site characteristics similar to those at the NRTS, Idaho, are assumed. In all other aspects, the cost estimate is treated as if it were an actual project for which a construction contract were contemplated. Based on the specified process and equipment, omitting escalation costs but including a contingency, Bechtel believes the accuracy of the capital cost is well within 20 percent of the final cost of such a plant were it built.

The capital cost estimate for the conceptual plant is summarized in Table II; a more detailed breakdown is given in Appendix C. The construction costs estimated by Bechtel Corporation included all costs associated with the engineering and construction of the plant, including the engineering-constructor's fee. Bechtel's estimate did not include land costs, process development, preliminary design and licensing activities, and other owner's costs, nor costs for a waste calcine canning facility and additional thorium storage tanks. These costs were estimated by Idaho Nuclear Corporation.

[a] Taxes will be encountered by any commercial reprocessor; their omission in this study is done to simplify the analysis. The proper tax rate to employ for an analysis such as this is dependent on the corporate tax structure as well as federal and state tax rates. 


\section{TABLE II}

CAPITAL COST SUMMARY FOR THE CONCEPTUAL PLANTI [a]

\begin{tabular}{cc}
$\begin{array}{c}\text { Bechtel } \\
\text { Estimated }\end{array}$ & $\begin{array}{c}\text { Idaho Nuclear } \\
\text { Estimated }\end{array}$ \\
Costs & Additional Costs \\
\hline
\end{tabular}

I. Direct Construction Costs
A. Structures and improvements
B. Process equipment
C. Auxiliary equipment
$\$ 11,360,000$
$12,680,000$
$8,960,000$
$\$ 3,620,000[b]$
$2,970,000$

II. Indirect Construction Costs
A. General and administrative
B. Engineering, design, and inspection
C. Miscellaneous construction
D. Contingency
E. Spare parts
F. Non-installed equipment spares
G. Quality assurance

$$
\begin{array}{r}
9,600,000 \\
9,400,000 \\
7,700,000 \\
200,000 \\
100,000
\end{array}
$$

$$
\begin{gathered}
2,238,000^{[c]} \\
974,000 \\
452,000 \\
1,097,000 \\
1,940,000
\end{gathered}
$$

\section{Owners Costs}
A. Land and land rights
B. Research and development
C. Interest during construction
D. Preliminary design and licensing
Total Construction Costs

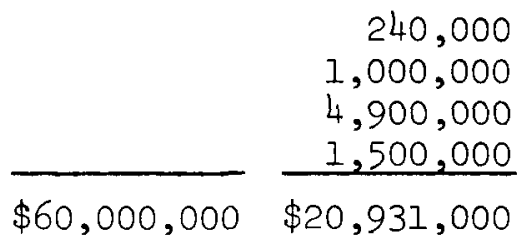

IV. Working Capital

Total Capital Costs

(Bechtel and Idaho Nuclear)

$1,100,000$

$\$ 82,031,000$

[a] Including capital costs of $\$ 11,415,000$ incurred after plant startup for waste calcination and canning facilities and added thorium storage tanks.

[b] Composed of $\$ 1,450,000$ for a calcine canning facility, $\$ 1,640,000$ for an additional extraction system, and $\$ 3,500,000$ for two additional thorium nitrate storage facilities (one of the three required storage facilities was included in the estimate by Bechtel).

[c] Based on seven percent of the direct construction costs incurred before plant startup. 
In preparing the construction cost estimate, the following assumptions, bases, and procedures were used by Bechtel.

(1) The single-purpose, self-contained plant would be owned and operated by a private company.

(2) The engineer-constructor would be responsible for the complete installation of the fuel processing plant including detailed engineering, procurement, construction, and mechanical checkout.

(3) Cost estimates were based on the flowsheets and criteria prepared by Idaho Nuclear Corporation.

(4) Equipment pricing was based on actual commercial plant equipment quotations with allowance for cost escalation to July 1969.

(5) Pricing for other material and subcontracts was made from preliminary drawings, flow diagrams, and design data.

(6) Construction wage rates for a near-average U. S. area (Denver, Colorado) were used. Payroll taxes, insurance, and fringe benefits were included in direct labor rates.

(7) Engineering design and inspection costs were determined from a man-hour estimate based on past experience and on current projects of a similar magnitude. Man-hours were priced using 1969 rates and include overhead of 75 percent of salaries. Estimating and procurement functions are included in this category.

(8) Miscellaneous construction costs cover temporary field construction, field records, equipment rental, and other costs incurred at the construction site which are not directly chargeable.

(9) Contingency was added to cover costs which were not specifically identifiable at this stage of the project, but which would be absorbed as the project progressed into detailed design. It does not cover escalation or major changes in plant scope.

(10) Costs of spare parts were based on an average value of parts which would be kept on hand to immediately correct malfunctions in essential items such as process equipment, utilities, manipulators, instrumentation, etc. Parts requirements were estimated as a varying percentage of direct material costs considering equipment complexity, service, and the likelihood of local warehousing of required items. 
(11) Non-installed spares are those items, especially fabricated for the plant or vital to continued operation, which would be stored on-site for immediate replacement.

Bases for owner's costs estimated by Idaho Nuclear Corporation are:

(1) A land cost of $\$ 400$ per acre was assumed.

(2) General and administrative costs were assumed to be seven percent of the direct construction costs before startup as recommended in the Guide to Nuclear Power Cost Evaluation [16].

(3) Interest during construction was assumed to be eight percent per year based on the debt portion of the capital expended during construction.

(4) Working capital requirements were based on 45 days of operating expense.

(5) Development costs before startup were included as part of the capital investment since this work primarily would be required only for this project. These costs were assumed to be $\$ 200,000$ per year for five years prior to startup. Significant research and development work was assumed to have been completed at an earlier date.

(6) Quality assurance costs based on refinery and chemical plants were included in the Bechtel estimate; however, its estimate does not reflect quality assurance costs anticipated for a nuclear fuel processing plant being built in the near future. An additional cost of three percent of the Bechtel estimate has been assumed to reflect costs for more stringent quality assurance than originally considered in this study.

(7) Preliminary design and licensing costs were estimated to be $\$ 1.5$ million ( $\$ 1$ million per year for $1-1 / 2$ years).

Capital costs for a facility for canning and shipping solid wastes to a Federal Repository and for added thorium storage (Bechtel's estimate included thorium storage capacity for only five years of processing) were determined as follows:

(1) Capital costs for the solid waste canning and shipping facility were based on an estimate for similar facilities to handle calcined wastes from the Waste Calcining Facility at the Idaho Chemical Processing Plant (ICPP).

(2) Capital costs for added thorium storage were taken from Bechtel's estimate.

The project schedule and annual capital expenditure distributions are provided in Figures 2 and 3, respectively. 


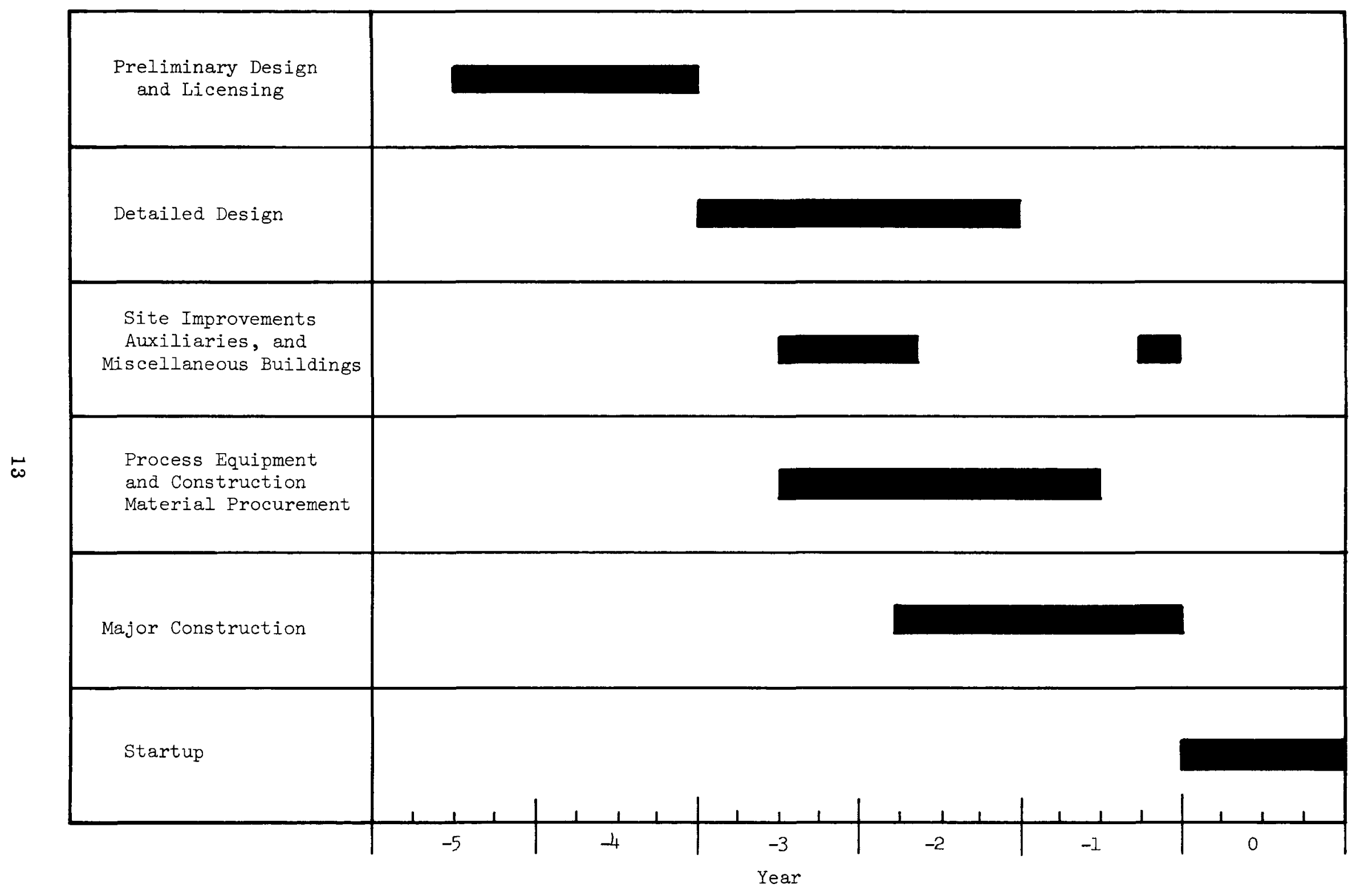

FIG. 2 PROJECT SCHEDULE. 


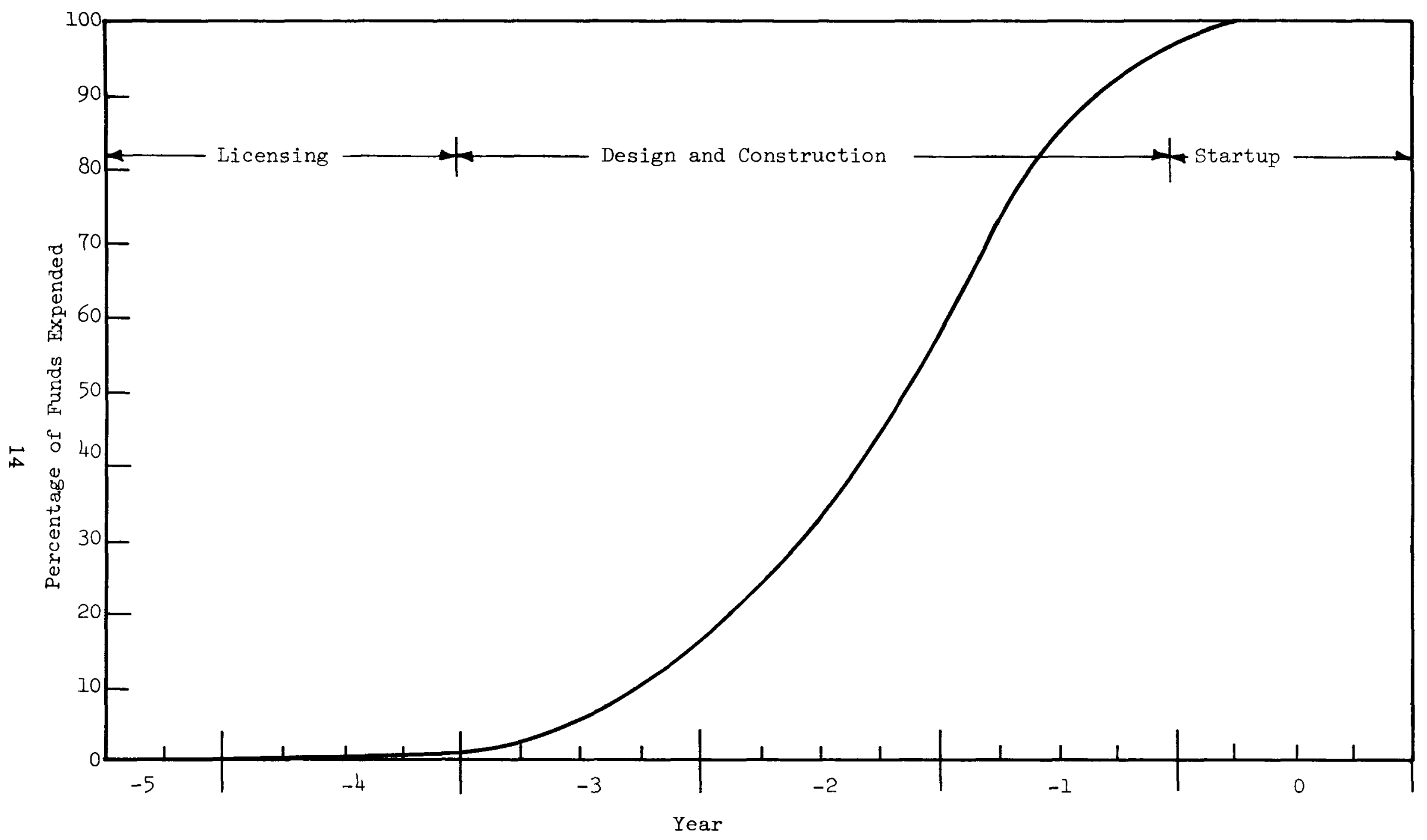

FIG. 3 CAPITAL EXPENDITURE DISTRIBUTION. 


\section{OPERATING COST ESTIMATES}

Operating costs for full production rate were developed for the conceptual plant based on published cost factors as shown in Table III and from past experience in the operation of ICPP. Costs summarized in Table III are divided into four primary groups -- costs proportional to labor, investment, and production rate, and miscellaneous costs. Depreciation is not included in the operating costs because the economic model includes recovery of the capital investment and is on a before-tax basis. Interest on the debt is not included as an operating cost but is included in the uniform annual repayment of the debt. Chemical costs are based on published prices ${ }^{[17]}$.

Costs proportional to labor include wages and salaries for 305 personnel, a labor burden of 26 percent of wages and salaries for benefits, and a fourpercent allowance for supplies; total annual costs proportional to labor amount to $\$ 3,696,000$. The estimated number of personnel for the conceptual plant and their salaries are itemized in Appendix D.

Costs proportional to investment include those for maintenance materials and an allowance for equipment replacement, insurance, and property taxes. Maintenance materials are assumed to be one percent, insurance costs (including nuclear liability) eight-tenths of one percent ${ }^{[18]}$, and property tax one percent of the capital investment (excluding working capital and interest during construction). Interim replacement costs were determined for estimated service lives of the equipment. This cost covers only the replacement of major equipment. Costs for minor equipment replacement such as valves, screens, piping, and instrumentation are included in annual costs for maintenance materials. A onetime startup cost is estimated at 10 percent of the initial capital investment (excluding the $\$ 11,445,000$ capital cost incurred after plant startup). In the economic analysis, funds for replacement are disbursed in the year of occurrence. Total annual costs proportional to investment are estimated to be $\$ 2,129,000$.

Those costs proportional to the production rate amount to $\$ 2,290,000$ annually and consist of allowances for chemicals, utilities, and waste disposal. Annual chemical requirements for the conceptual plant are itemized in Appendix E. 
CONCEPTUAL PLANT OPERATING COST SUMMARY [a]

(Dollars per Year)

I. Costs Proportional to Labor
A. Wages and salaries
B. Labor burden ( $26 \%$-- benefits, etc)
C. Other burden ( $4 \%$-- supplies)
$\$ 2,843,000$
739,000
114,000
Subtotal
$\$ 3,696,000$

II. Costs Proportional to Investment (Fixed Costs)

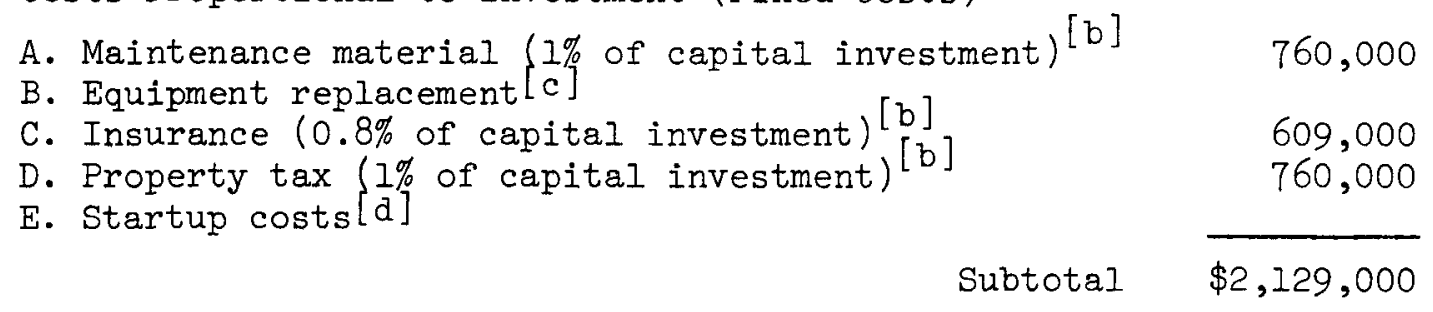

III. Costs Proportional to Production Rate
A. Direct materials (chemicals, etc)
B. Utilities
C. Calcined waste disposal
D. Fissile particle disposal
530,000
395,000
421,000
944,000
Subtotal $\$ 2,290,000$

IV. Miscellaneous Costs

A. Research and development

B. Home office expense ( $7 \%$ of operating costs)

100,000

575,000

Subtotal

$\$ 675,000$

Total Operating Costs $\$ \overline{8,790,000}$

[a] Based on full production rate through conceptual plant.

[b] Excluding working capital and interest during construction.

[c] Equipment replacement costs were assumed to occur during the year of replacement. A total expenditure of $\$ 2,340,000$ was estimated for replacements over the lifetime of the plant.

[d] Startup costs were estimated to be $10 \%$ of the capital investment before startup or a total of $\$ 6,454,000$. This onetime cost occurs in the year prior to production processing. 
Waste disposal costs include those for canning, shipping, and government charges at the repository. These costs are itemized in Appendix F.

Miscellaneous costs for research and development amount to $\$ 100,000$ annually and an annual home office expense of $\$ 575,000$ is assumed (seven percent of operating costs).

\section{METHOD OF DETERMINING THE BATCH PROCESSING CHARGE}

The daily processing charge $(\$ 130,000 /$ day) for the conceptual HTGR fuel processing plant is based on an operation in which separate accountability of each batch of fuel is not required. The plant is assumed to process 260 tonnes (after burnup) of thorium and uranium annually during 250 actual processing days (except during the first two years after hot startup). Two days each month are reserved to heel-out the facilities for criticality considerations. Based on these assumptions, the plant could process a maximum of 1.04 tonnes of thorium and uranium per day. The charge for processing a batch of reference fuel is determined by using the following equation:

$$
\text { Processing charge }=\mathrm{D}(\mathrm{W} / \mathrm{R})
$$

where

$$
\begin{aligned}
\mathrm{D}= & \$ 130,000 \text { (the daily charge for operation of the conceptual } \\
& \text { HTGR plant) } \\
\mathrm{W}= & \text { weight in kilograms of thorium and uranium in the fuel } \\
& \text { batch to be processed through the extraction system } \\
\mathrm{R}= & 1040 \text { (daily processing rate in kilograms of thorium and } \\
& \begin{array}{l}
\text { uranium to be processed through the extraction system and } \\
\text { containing a maximum of } 120 \mathrm{~kg} \text { uranium). }
\end{array}
\end{aligned}
$$

For fuels other than the reference fuel, $R$, the daily plant processing rate, would have to be determined and substituted in the above formula in place of the 1040 kilogram figure used for the reference fuel. The calculated charge for the processing service excludes all shipping costs both for the incoming spent fuel and for outgoing purified product. No product losses are assumed in the processing charge determination. 


\section{ADJUSTMENT OF THE DAILY CHARGE}

The daily processing charge is adjusted for changes in the economy by applying cost indices to the capital and operating portions of the daily charge. The portion of the daily charge related to capital cost can be adjusted to reflect changes in price levels since the July 1969 base date by using monthly construction cost indices ${ }^{[19]}$. Likewise, the portion related to the operating cost can be adjusted by using an index such as the inorganic chemicals cost index [20].

Sensitivity analyses indicate that 80 percent $(\$ 104,000)$ of the daily charge for processing is capital related and 20 percent $(\$ 26,000)$ is operating related. These dollar amounts are adjusted from the July 1969 basis by the following equation:

$$
\mathrm{D}_{\mathrm{a}}=\$ 104,000 \mathrm{M}+\$ 26,000 \mathrm{~N}+
$$

where

$$
\mathrm{D}_{\mathrm{a}}=\text { daily processing charge adjusted for escalation }
$$

$\$ 104,000=$ capital portion of the daily processing charge

$$
\mathrm{M}=\frac{\mathrm{IC}_{\mathrm{f}}-\mathrm{IC}_{\mathrm{p}}}{\mathrm{IC}_{\mathrm{p}}}
$$

$\mathrm{IC}_{\mathrm{f}}=$ Official Monthly Construction Cost Index for some future date

$I_{p}=$ Official Monthly Construction Cost Index for July 1969 $\$ 26,000=$ operating portion of the daily processing charge

$$
\mathrm{N}=\frac{\mathrm{IO}_{\mathrm{f}}-1 \mathrm{IO}_{\mathrm{p}}}{\mathrm{IO} \mathrm{O}_{\mathrm{p}}}
$$

$1 O_{\mathrm{f}}=$ Index for Inorganic Chemicals for some future date $\mathrm{IO}_{\mathrm{p}}=$ Index for Inorganic Chemicals for July $196 \mathrm{y}$ 


\section{CONCLUSIONS}

Capital and annual operating costs for the AEC Conceptual HTGR Fuel Processing Plant are estimated to be $\$ 82,031,000$ and $\$ 8,790,000$, respectively. The daily charge for plant operation is calculated to be $\$ 130,000$ as of July 1969. 


\section{REFERENCES}

1. Federal Register, Spent Fuels, Chemical Processing and Conversion (January $3,1968) \mathrm{p} 30$.

2. USAEC, “Thorium Fuel Cycle”, Proceedings of Second International Thorium Fuel Cycle Symposium, Gatlinburg, Tennessee, May 3-6, 1966, CON F-660524 (February 1968).

3. E. L. Nicholson et al, Burn-Leach Processes for Graphite-Base Reactor Fuels Containing Carbon-Coated Carbide or Oxide Particles, ORNL-TM-1096 (April 1965).

4. L. M. Ferris, Acid Leaching of Products from the Fluidized-Bed Combustion of Graphite-Base Reactor Fuels and the $\mathrm{HF}-\mathrm{O}_{2}$. Disintegration of Stainless Steel- and Zirconium-Clad Oxide Fuels, ORNL-3876 (November 1965).

5. J. R. Bower (ed.), Chemical Technology Branch Annual Report: Fiscal Year 1967, IN-1087 (October 1967).

6. R. E. Commander et al, Operation of the Waste Calcining Facility with Highly Radioactive Aqueous Waste, Report of the First Processing Campaign, IDO-14662 (June 1966).

7. Federal Register, USAEC Charges for Plutonium and Uranium Enriched in U-233 (May 24, 1969) p 8173.

8. E. D. Arnold, "Radiation Hazards of Recycled U-233-Thorium Fuels", from Proceedings of the Thorium Fuel Cycle Symposium, Gatlinburg, Tennessee, December 5-7, 1962, TID-7650.

9. Public Service Co. of Colorado, Fort St. Vrain Nuclear Generating Station, Unit No. 1: Preliminary Safety Analysis Report, 1, Docket 50267-8 (September 1966).

10. R. H. Rainey and J. G. Moore, Laboratory Development of the Acid Thorex Process for Recovery of Consolidated Edison Thorium Reactor Fuel, ORNL-3155 (May 1962).

11. R. E. Blanco et al, Aqueous Processing of Thorium Fuels, ORNL-3219 (March 1962).

12. HTGR Base Program Quarterly Progress Report for the Period Enaing February 28, 1967, GA-7801 (Apri1 1967). 
13. A. A. Kishbaugh, Performance of a Multi-Stage Centrifugal Contactor, DP-841 (October 1963).

14. A. S. Jennings, A Miniature Centrifugal Contactor, DP-680 (March 1962).

15. A. T. Clark, Jr., Performance of a Ten-Inch Centrifugal Contactor, DP-752 (September 1962).

16. Kaiser Engineers, Guide to Nuclear Power Cost Evaluation, Supplement 1, TID-7025 (September 20, 1962).

17. Oil, Paint, and Drug Reporter: The Chemical Marketing Newspaper, 196, No. 11 (September 15, 1969).

18. USAEC, Costs of Nuclear Power, TID-8531 (Rev. January 1961).

19. Engineering News Record, McGraw-Hill Publishing Company.

20. Wholesale Prices and Price Indexes, U. S. Bureau of Labor Statistics.

21. D. A. Orth and T. E. Olcott, Purex Process Performance Versus Solvent Exposure and Treatment, DPSPU 62-30-19A (October 1962).

22. Federal Register, AEC Rules and Regulations, Title 10, Part 20.

23. J. T. Barraclough et al, Hydrology of the NRTS, Idaho, 1966, IDO-22049 (October 1967).

24. R. L. Nace et al, Geography, Geology, and Water Resources of the NRTS, Idaho. Part 2. Geography and Geology, IDP-22033-2-USGS (1956).

25. G. A. DeMarrais and N. F. Islitzer, Diffusion Climatology of the NRTS, IDO-12015 (April 1960). 
0 
APPENDIX A

DESCRIPTION OF PROCESS AND FACILITY 
- 


\section{APPENDIX A}

\section{DESCRIPTION OF PROCESS AND FACILITY}

The Conceptual HTGR Fuel Processing Plant is a single-purpose, selfcontained plant designed to process 260 tonnes of heavy metals per year from HTGR reference fuel. A brief description of the process is given in Section II; a more detailed description of the process and a facility description are given in the following sections.

\section{DESCRIPTION OF PROCESS}

When received, HTGR fuelelements are placed in containers in a dry storage vault to await processing. The fuel elements are then transferred to a headend facility where they are crushed. The crushed fuel is continuously burned in a fluidized bed to expose the fertile and fissile particles. The particles and a portion of the bed material are continuously removed from the burner and separated by screening. Alumina particles are recycled to the burner, and the fissile particles are placed in storage. The fertile particle stream is then processed to recover the contained U-233. A condensed chemical flowsheet for processing HTGR reference fuel is shown in Figure $A-1$.

\section{HEADEND}

Preparation of burner feed starts when fuel elements which have been cooled for the specified 210 days are transferred either to the fuel cutting equipment or directly to the crushers, depending upon the particular fuel type under consideration. Significant portions of certain fuel elements may not contain any fuel meat or may not be compatible with either the crushing or burning operations. This type of fuel is to be diverted, therefore, to the fuel cutting equipment for the purpose of reducing its size or removing undesirable constituents.

\subsection{Bulk Fuel Process}

Following their transfer, either directly from storage or via the fuel cutting equipment, the fuel elements are mechanically reduced in size by crushers to pieces about one inch in diameter. The primary objectives of the size reduction are (a) to assure a more continuous, rather than intermittent, feed to the burner 

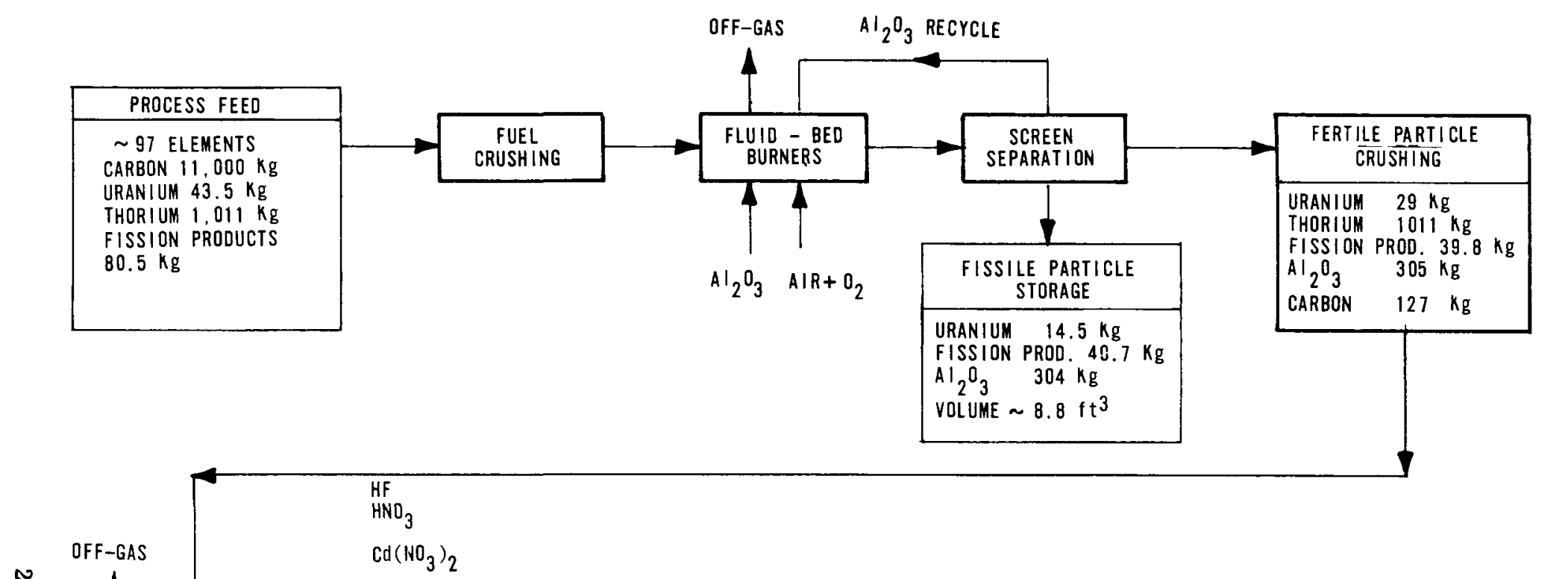

$\approx \quad$ OFF-

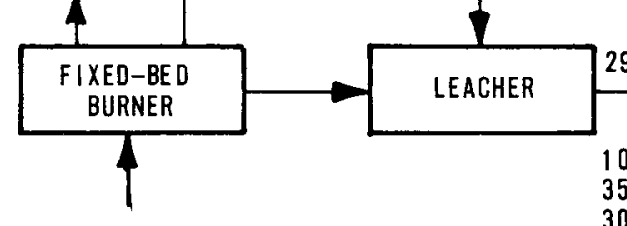

$\mathrm{AIR}+\mathrm{O}_{2}$

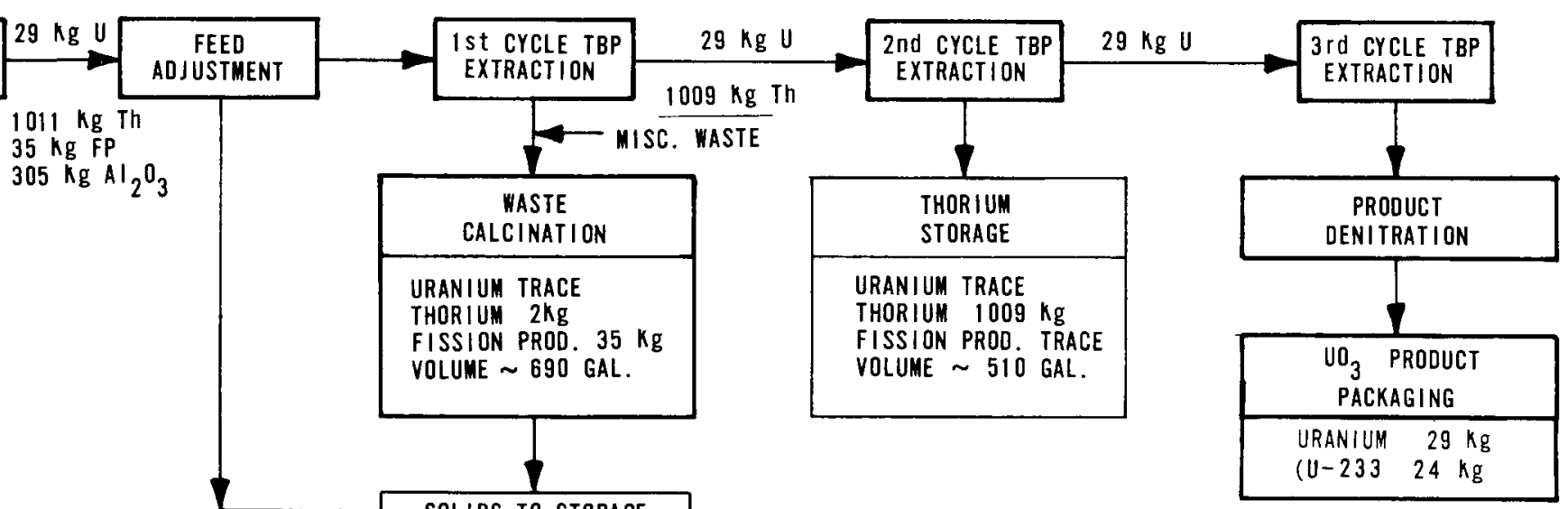


and (b) to promote efficient burner operation by providing a larger surface area for combustion of the fuel.

Each of the burners has a separate crushed fuel hopper and air-lock feeder associated with it. Thus, following the fuel block crushing operation, the crushed fuel is collected in hoppers and then fed to the burners at a controlled rate by the individual air-lock feeders. Alumina particles are added continuously to the fluidized-bed burners through separate entry lines.

The combustion process, conducted in the temperature range from 1300 to $1400^{\circ} \mathrm{F}$ with varying oxygen concentrations, allows the silicon-carbide-coated fuel particles to remain intact ${ }^{[12]}$. However, up to ten percent of both the fissile and fertile particle coatings may be fractured from a variety of causes. This results in (a) coating of alumina particles with quantities of thorium, uranium and fission products oxides and (b) the release of both gaseous and volatile fission products in the burner. Therefore, routine leaching of the alumina is necessary.

During combustion, released halides, noble gases, and volatile fission products largely exit with the burner off-gas. The sintered metal filters within the burners serve to remove entrained particles from this stream. Then the gas is cooled and passed through a packed-bed silica-gel adsorber to remove ruthenium oxides; any cesium oxide escaping the sintered filters probably is removed also, but to a lesser extent than ruthenium. Prior to discharge via the plant stack, residual particulate matter is removed from the off-gas by roughing and high-efficiency filters. Gaseous fission products are diluted in the stack with ventilation air to maintain concentration levels below release limits.

Burner ash, a mixture of alumina, fuel particles, heavy metals, and fission products, is withdrawn through a side removal line near the bottom of the bed; a bed drain line is also provided to allow removal of the entire contents of the bed prior to maintenance operations or during emergencies. Normally, the burner ash is transported pneumatically to a hopper prior to screening. However, during emergencies, the entire bed is dumped to a bed storage hopper. The ash may contain a significant quantity of fines, some of which may be unreacted graphite. The exact quantity of graphite depends largely on burner operating conditions. Any fines entrained in cooling air streams are removed by sintered metal filters; a pulse blowback system is used to return the fines to one of the fluidized-bed burners. 
A screener divides the burner ash into the following three main streams: (a) fertile particles, (b) alumina, and (c) fissile particles. The fissile particle stream contents are placed in containers and the containers are stored in a water-filled storage basin prior to shipment to a Federal Repository.

\subsection{Fertile Particle Process}

The fertile particles are collected in a hopper or interim storage vessels after screen separation and prior to entering a crusher. The particle crusher breaks the silicon-carbide-coating on the particles. Crushed fuel particles pass from a collection hopper to a weigh hopper before being introduced into a fixedbed burner, where the buffer carbon is burned. Sintered-metal filters retain the solids within the burner while silica-gel adsorbers remove the bulk of the volatile fission products. The ash from the fixed bed burner is transferred to a storage hopper prior to leaching in a batch-type operation. The acid is added to the leacher and heated to boiling before introduction of the burner ash. The burner ash is added to the leacher over a several-hour period of time for adequate control of the foaming which initially occurs.

The leacher slurry is jetted to a centrifuge for separation of the leachate from the solids, and solids washing. Solids from the centrifuge, consisting mainly of alumina, silicon carbide hulls, and boron carbide, as well as some insoluble fission products, enter a drying hopper where they are dried with nitrogen and are then used as a diluent for the high-activity-level waste solids produced from calcining waste raffinate streams. The leachate and rinse solutions are combined with the leachate-rinse solution produced in the alumina cleanup cycle. The composite leachate then enters the feed adjustment system.

Feed adjustment consists of a nitric acidstripping operation and is required for the modified Acid-Thorex process, since the feed solution must be aciddeficient. Pilot plant studies ${ }^{[4,11]}$ have shown that the acid stripping can be satisfactorily accomplished by evaporating and steam-sparging the leachate in the steam stripper. The overhead from the stripper is a high molarity nitric acid solution which is reclaimed for recycle purposes.

The acid-deficient stripper product is continuously withdrawn from the stripper and enters a receiver tank. While the stripper product is being held in the receiver tank, an aqueous solution of sodium bisulfite, $\mathrm{NaHSO}_{3}$, is added

to improve ruthenium decontamination ${ }^{[4]}$ during solvent extraction. After the 
addition of the sodium bisulfite, the adjusted feed solution is transferred to the feed tank for the solvent extraction process.

\subsection{Alumina Cleanup Process}

As indicated previously, some coating of the alumina bed material is anticipated from heavy metals and fission products because of fuel particle breakage during reactor operation and headend processing. In addition, some contamination of the alumina stream with fuel particles is expected due to carryover from the screening operation. The estimated contamination level from these two sources is controlled at an equilibrium level of two percent of the alumina mass. Cleanup of the alumina on a once a month basis is believed adequate to remain at or below this level of contamination. To minimize downtime, the alumina is processed on a continuous basis, that is, approximately one-thirtieth of the alumina stream is processed daily.

Following separation of the alumina stream from the bulk of the burner product ash, a diversion valve splits the stream of solids into two parts with the major portion being recycled directly back to the burners, while the alumina to be processed is sent to an aluminastorage hopper. The coating is leached from the latter in a batch-type operation similar to that of the fertile particle process.

Alumina losses can occur by two independent means. The first loss can occur in the screening operation in which up to ten percent may be lost to the fertile and fissile particle streams as a result of particle attrition. The second loss of alumina can occur in the leacher operation where it is estimated that up to two percent may go into solution [4]. These losses are compensated by adding fresh alumina to the recyclestream just prior to its entry into the burner.

After completion of the leaching operation, the slurry is jetted to a centrifuge where the following operations take place sequentially: (a) leachate is removed, (b) the solids are rinsed, and (c) the solids are discharged and transported to a drying hopper. The alumina is dried using a heated air stream and then returned to the recycle stream. The leachate and rinse solutions are combined with the leachate rinse solution produced in the fertile particle cycle for further processing. 


\section{SOLVENT EXTRACTION OF FERTILE MATERIAL}

A modified Acid-Thorex flowsheet $[10,11]$ is used in processing the heavy metals leached from the fertile particles. Each of three cycles utilizes extraction, scrubbing, and stripping steps. The first cycle separates the bulk of the fission products from thorium and uranium, while the second cycle partitions thorium from uranium. Finally, the last cycle consists of an additional uranium purification cycle. The solvent wash system for five percent tributyl phosphate (TBP) is common for the extractant from the second and third cycles, while the first cycle extractant - 30 percent TBP - - uses an independent solvent wash system.

In the first extraction cycle, thorium and uranium are co-extracted from the feed solution by a solvent composed of 30 volume percent TBP in an inert diluent. The acid-deficient feed is continuously metered into a multi-stage centrifugal contactor. Greater than 99.9 percent of the fission products are removed in the waste raffinate stream. This stream is subsequently routed to waste processing for disposal with other high level wastes. The scrubbed extractant stream containing thorium and uranium is then fed to the strip column where thorium and uranium are stripped from the organic extractant. The first cycle product is reduced in volume by evaporation and fed into the second solvent extraction cycle.

In the second solvent extraction cycle, thorium and uranium are partitioned from each other and the uranium receives an additional decontamination. The second cycle feed is contacted in a pulsed column with an extractant containing five percent TBP in Amsco. By adjusting the relative feed and extractant flow rates and by selecting a suitable scrub stream, virtually all of the thorium remains with the aqueous raffinate. In addition, the acid scrub stream provides additional decontamination of the uranium-bearing solvent stream. The uranium is stripped back into the aqueous stream which is reduced in volume by evaporation.

Because of the presence of Th-228 from decay of $U-232$, thorium from irradiated HTGR fuel elements has a significantly higher radiation level than naturally occurring thorium. Cost of natural thorium is low enough that reuse of thorium in a fuel fabrication plant is not justified. After 15 years of storage, the Th-228 and daughters decay to levels comparable to natural thorium ${ }^{[8]}$. Therefore, the recovered thorium is stored after being reduced in volume by 
evaporation to the limits of thorium solubility. The concentrated thorium solution is subsequently sent to storage tanks.

The third extraction cycle provides the final uranium purification step. The final product (U-233) from the third cycle extraction is essentially free of fission product radioactivity; however, should product shipment be delayed by strikes, bad weather, etc, fission product activity would build up due to the daughters of the impurity U-232. To cope with possible shipping delays and insure that only freshly decontaminated product is shipped, the system contains interim storage tanks to collect second cycle product and oversized third cycle extraction equipment to handle the increased load due to the holdup. Waste raffinate from the third cycle is sent to intermediate level waste collection tanks for processing. Uranium solution is concentrated prior to being fed to a uranium product denitrator.

Two solvent wash systems are provided to remove impurities formed by radiolytic and chemical degradation of TBP and paraffin hydrocarbons during processing. Independent wash systems are required for the 5 and 30 percent TBP solutions. Removal of solvent degradation products is necessary for proper chemical and mechanical operation of the solvent extraction system. In both solvent wash systems, the solvent effluent from the strip column(s) is contacted with a dilute solution of sodium carbonate in a pulsed column and then with dilute nitric acid in a packed column. The washed solvent overflows to a solvent storage tank for return to the extraction columns. Periodically, the wash waste is transferred through a decanter to the intermediate-level waste system for disposal. When necessary, fresh makeup solvent may be added to the systems.

After long processing periods, certain degradation products, which were not removed in the solvent washing system, build up in the extractant and form complexes with some fission products, namely, zirconium and niobium ${ }^{[21]}$. Periodically as these degradation products build up in the solvent, the solvent must be discarded and replaced. For disposal, this degraded solvent is burned as a fuel in the waste calcining facility.

\section{PRODUCT}

The concentrated U-233 product could be routed to the uranium loadout area for transport to a fuel refabrication plant as a nitrate solution if the 
refabrication plant were adjacent to the processing plant. In the event that the refabrication plant is not located in the vicinity of the reprocessing facility (as is assumed in this report), denitration and conversion to solid uranium trioxide are desirable. Denitration of the $\mathrm{U}-233$ product stream is accomplished in a fluid-bed denitrator and the product is subsequently packed for shipment to the fuel refabricator. 


\section{CONTROL OF NUCLEAR HAZARDS}

The general philosophy for control of nuclear hazards in the plant requires control of the radiation dose to operating and maintenance personnel, freedom from contamination by radionuclides in controlled areas, and the elimination of any risk of a nuclear excursion due to the accumulation of critical quantities of uranium. Finally, control of nuclear hazards outside the plant requires the elimination of risk to the population at large which could result from the uncontrolled release of gaseous, liquid, or solid wastes.

\section{RADIATION CONTROL}

Throughout the plant, radiation control is effected by concrete shielding of appropriate thicknesses as the primary protection. Shielding in the process building is adequate to protect plant personnel from radiation during normal

operation, based on AEC guidelines [22]. Penetrations through shielding walls, floors, windows, piping, etc, are designed to provide shielding equivalent to the wall, as required.

\section{CONTAMINATION CONTROL}

Traffic flow and ventilation paths within the plant prevent the flow of contaminants from a high-concentration to a low-concentration area; health-physics checkpoints serve areas of potentially high contamination. A slight vacuum on the entire processing building prevents any unfiltered leakage from the building. Egress from and access to the building are through vestibules or normally noncontaminated areas that serve as buffer zones between the outside and areas of contamination within the building. Radioactive areas operate at a negative pressure with respect to operating areas, with exhaust capacity adequate to insure that a pressure difference of at least 0.5 in. water is maintained at all times between radioactive and operating areas. 


\section{CRITICALITY CONTROL}

Normally accepted radiochemical safety design practices are assumed for protection of both personnel and equipment. Nuclear criticality is controlled in process equipment and vessels by one or a combination of the following:
(1) Designing geometrically safe systems
(2) Limiting mass concentrations
(3) Using soluble neutron poisons in solutions
(4) Using grids containing nuclear poison. 


\section{EFFLUENT DISPOSAL}

During fuel processing, radioactive contaminants in the gaseous waste are removed to levels that permit safe environmental release. Process off-gas is passed through silica gel adsorbers to remove primarily ruthenium, then filtered through roughing and high-efficiency filters and monitored before discharge via a 400-foot-high stack to the environment. The stack height is based on a maximum dose limit of $170 \mathrm{mR} / \mathrm{yr}$ to a general population as listed in 10CFR20 of the Federal Register. The dose is assumed caused from $\mathrm{Kr}-85$. However, most of the tritium in the fuel elements is also discharged through the stack. Ventilation air from the cells is also filtered through both roughing and highefficiency filters and then monitored before discharge. Some liquid waste, after being stripped of essentially all radioactivity by ion exchange facilities, is discharged to the ground water, but only if it meets permissible criteria. All other liquid wastes are concentrated by evaporation to high-level waste, stored for a minimum of two years, converted to solid particles by the fluidized-bed calcination process, and stored in underground vaults in small diameter bins. The bins are constructed such that the calcine is retrievable, after sufficient cooling, for shipment to an off-site Federal Repository. Other less radioactive bulk-solid wastes are packaged for off-site burial. 


\section{PLANT DESIGN}

The Conceptual HTGR Fuel Processing Plant is developed to be a minimumcost plant within the framework of current and proposed AEC regulations governing the licensing and operation of such facilities.

\section{PLANT SITE AND GENERAL PLANT LAYOUT}

The location of the conceptual plant is assumed to be similar to that of the National Reactor Testing Station, Idaho $[23,24,25]$, in an area of low population density. The site is relatively level with local drainage handled by a system of ditches and pipe culverts. The type of soil precludes any unusual or elaborate foundation requirements, and the site has adequate underground water and electrical power available. Ready access to the site by railroad and highway is assumed.

Most of the plant facilities are contained within a small security area located in the center of a 600-acre area, approximately 1-1/4 miles long and 3/4 mile wide aligned with the long axis in the direction of the prevailing wind. The security area is enclosed by a chain link fence and is lighted. Access to this area is through a guard gate house. A parking area is provided for approximately 200 cars outside the security area adjacent to the gate house. Paved roads, extending from the main highway to the plant site, connect all buildings, and small areas are provided for parking at most of the plant buildings. A railroad spur track is extended from the main rail lines in the area to service the fuel storage area. The general plant layout is shown in Figure A-2.

The plant is composed of four main buildings. The processing building contains all of the radioactive processing equipment and other required radioactive operations such as spent fuel storage, analytical, decontamination, and waste treatment, plus some office space. The administration building contains offices, reception and conference rooms, medical and first-aid offices, as well as a lunch room, a modest library, and a mail room. The auxiliary building houses the boilers, emergency diesel generators, compressors, and dryers. A combination warehouse and plant-equipment maintenance shop is provided. 


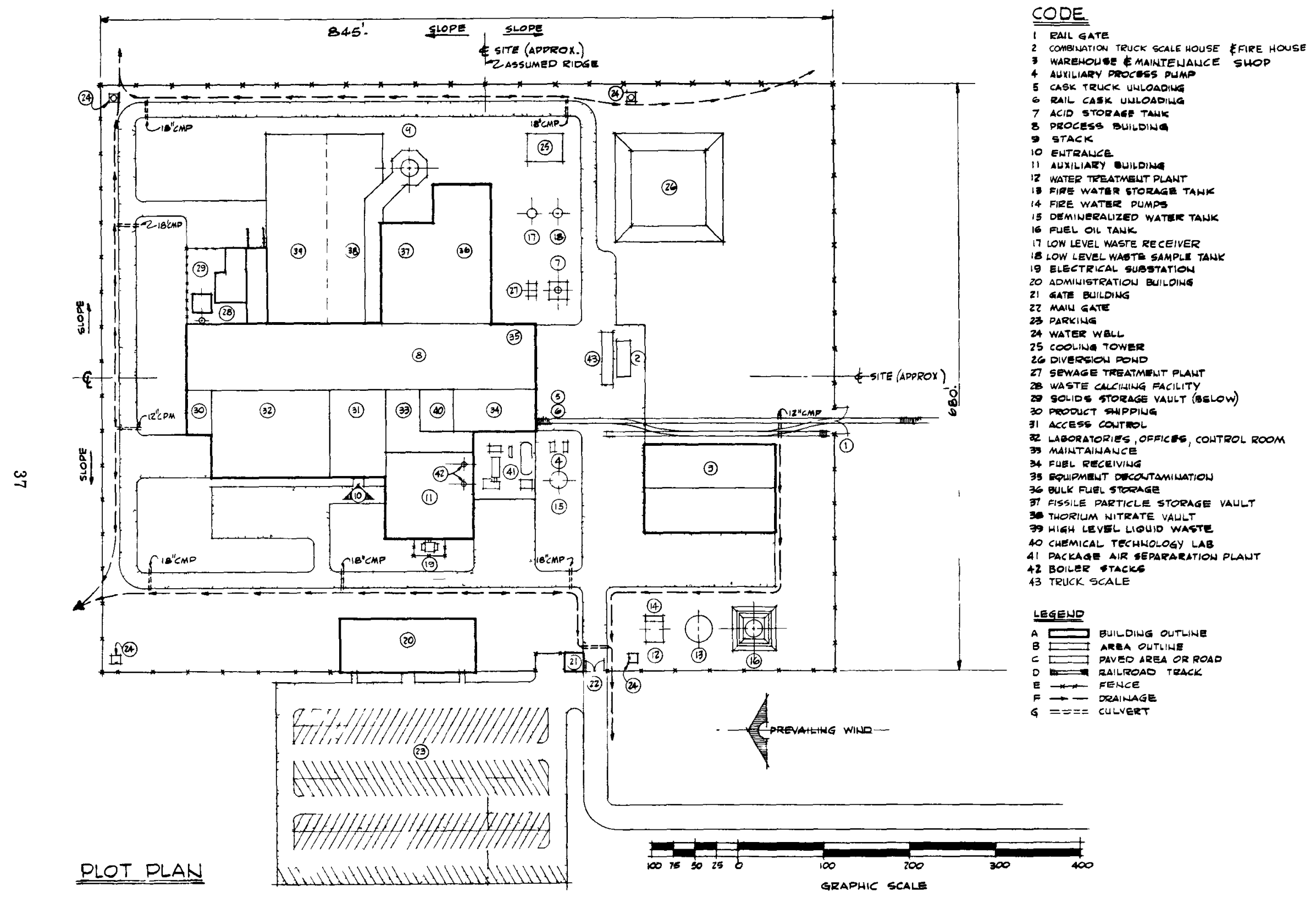

FIG. A-2 GENERAL PLANT LAYOUT 
The process building incorporates a compact arrangement and plot plan to minimize shielding concrete and the length of piping runs. The processes are arranged so that storage and handling of highly radioactive material are below grade where practical. The majority of normally clean operations are carried out on one side of a linear arrangement of process cells, while those which might be a source of radioactive contaminants are carried out on the opposite side. All waste storage is at the rear of the facility while offices, laboratories, and access are at the front.

A package air separation plant, located near the process building, is provided to supply oxygen to the graphite burners. This plant also provides nitrogen gas for conveying and cooling solids in the headend process. Nitrogen is used to provide an inert atmosphere should the fuel contain carbide rather than oxide fuel. The nitrogen is obtained at essentially no cost as it would be a waste gas from the oxygen plant if not utilized. The use of nitrogen, even with oxide fuels, lessens the probability of accidental burning of finely divided graphite or fuel in the transport lines or collection vessels.

\section{FUEL RECEIVING AND STORAGE}

Spent fuel, canned or uncanned, is received in large shielded shipping casks at the fuel receiving facility. This facility is designed to receive shipments by either rail or truck. A cask is removed from the vehicle by an overhead crane, placed in an upright position for examination, and then lowered into the unloading pit. In the unloading pit, the cask is washed to remove dirt and dust prior to unloading. A shield plug is then placed over the unloading pit and the cask lid is removed and clamped to the plug prior to unloading the fuel from the cask with remote manipulators. Uncanned fuel elements are placed in reusable containers before being transferred into the fuel storage area.

Fuel elements are transferred from the shipping cask to the storage containers in the cask unloading pit by a telescoping boom manipulator. The manipulator also is used to attach a lifting lid to the loaded containers and transfer the containers to a remotely operated dolly which shuttles back and forth in a tunnel between the loading pit and fuel storage vault. Fuel received in storable containers is transferred directly from the cask to the dolly. 
The fuel storage containers are moved from the transfer dolly to a location in the vault by a remotely operated overhead crane. This crane also moves the containers from the vault to the fuel cutting and crushing cell where the processing operations start.

The fuel storage vault is a partially underground structure providing storage space equivalent to 60 days of processing. The storage containers rest on spring-loaded trap doors which open under load to a plenum and allow cooling air to flow around the containers. The containers are supported laterally near their tops by an angle iron lattice.

\section{PROCESS AREA ARRANGEMENT}

The major process areas are arranged in a line with specialized functions being carried out in separate cells. In the dry headend process, flow of materials is by gravity within the cells and by pneumatic transfer between cells. In the aqueous processes, transfer is by gravity, steam jet, or air lift, as appropriate. The general layout of the process cells is shown in Figures A-3 and A-4.

The arrangement of equipment within the cells is also shown in Figure A-4. The cell name describes the major equipment in the dry headend cells. For the aqueous processing cells, the remote chemical process cell contains leachers, centrifuges, and first-cycle contactors; the high level cell contains the high level waste system, the stripper, and the waste rework system; the highintermediate level cell contains the intermediate level waste system and the remaining first-cycle extraction system; the intermediate level cell contains the front end of the first-cycle solvent cleanup system, the second-cycle extraction equipment, and the low-level waste system; the low level cell contains third-cycle extraction equipment, a second solvent cleanup system, and the tail end of the first-cycle solvent cleanup system.

\section{EQUIPMENT MAINTENANCE}

A combination of remote and contact maintenance is used in the plant. Equipment in high radiation areas with a high expected maintenance frequency are either repairable or replaceable remotely; all other equipment is designed for contact maintenance. 
All cells have roof hatches which provide access to the equipment within the cells. Equipment in the cells is located to facilitate vertical removal without disturbing adjacent pieces of equipment. Contaminated equipment can be trans ferred from the process cells to the washdown and decontamination cells through the access hatches.

Within the headend cells, provisions are made for some remote maintenance of a simple nature. Operations of this type would include replacement of filters, bed heaters, and instrumentation; freeing of valves; and making and breaking connections. More complex operations involving major equipment overhaul would require decontamination prior to opening the cells and retrieving the particular equipment involved for transfer to the hot maintenance cell. Where required, operations within cells are normally viewed through strategically located shielding windows. Closed circuit television is provided in areas where only inspection and viewing are required. 


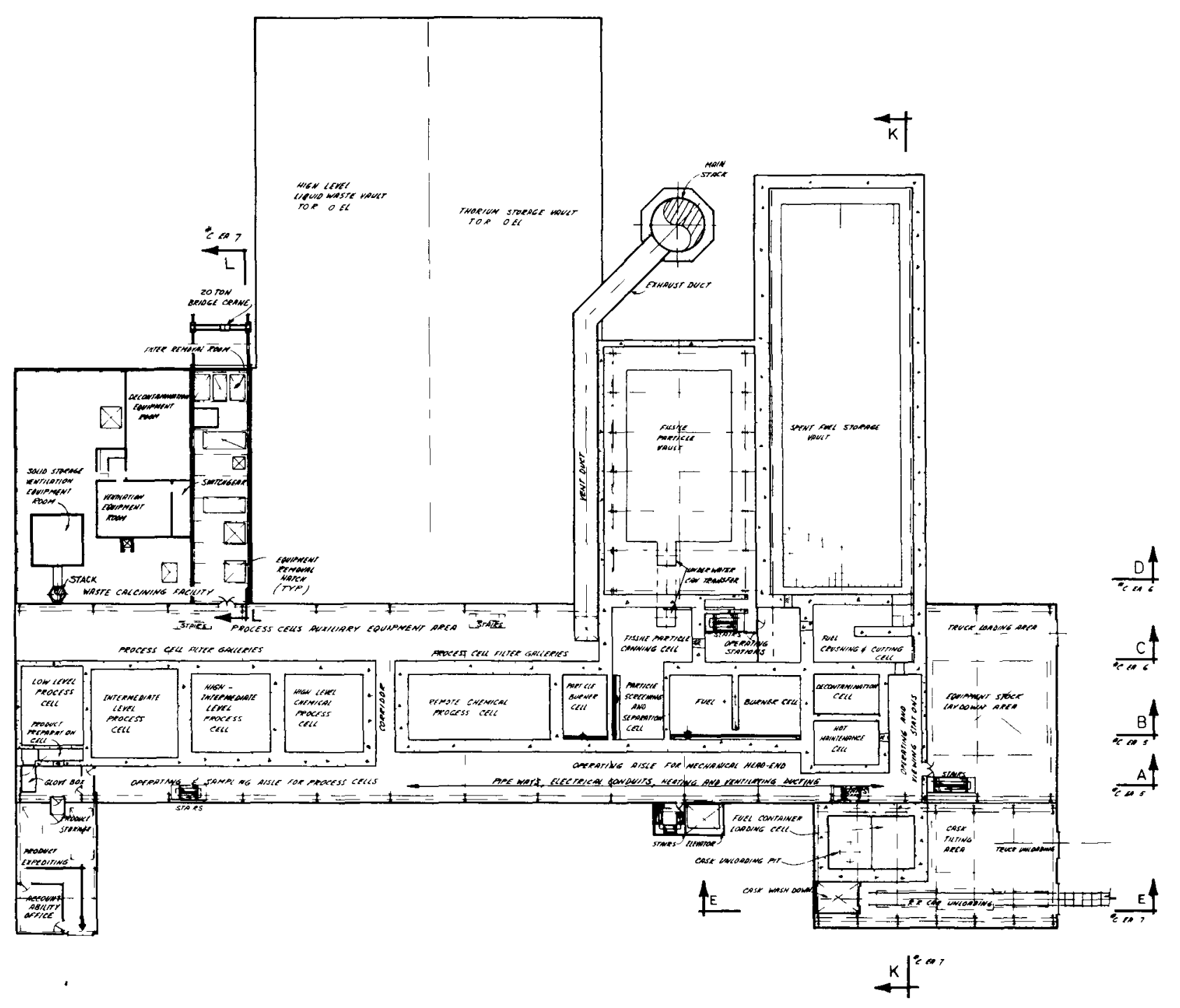

PLAN AT GRADE 


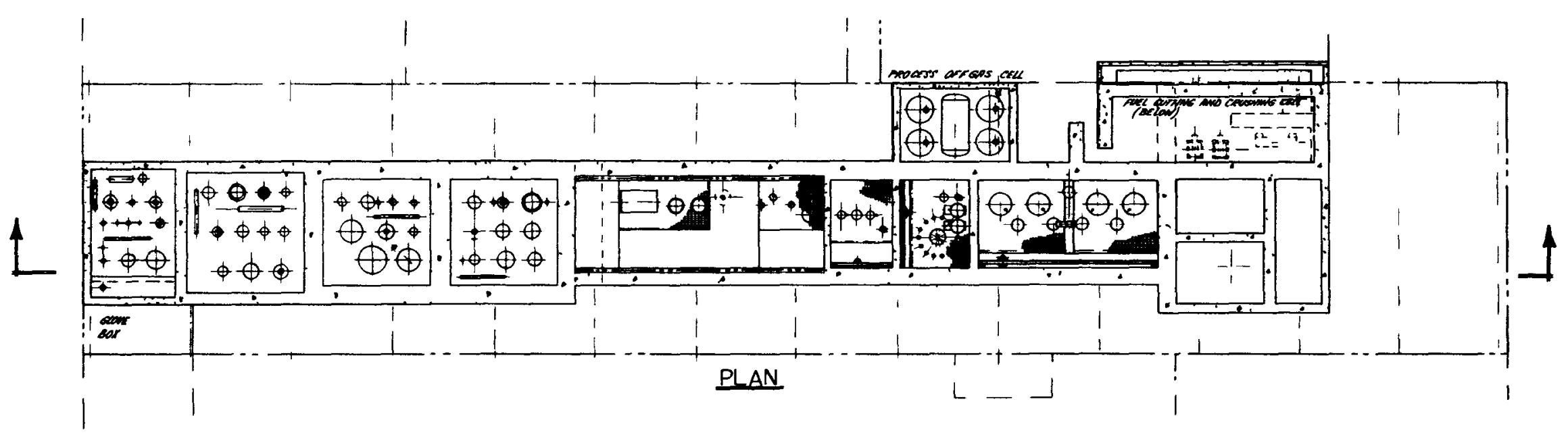

:

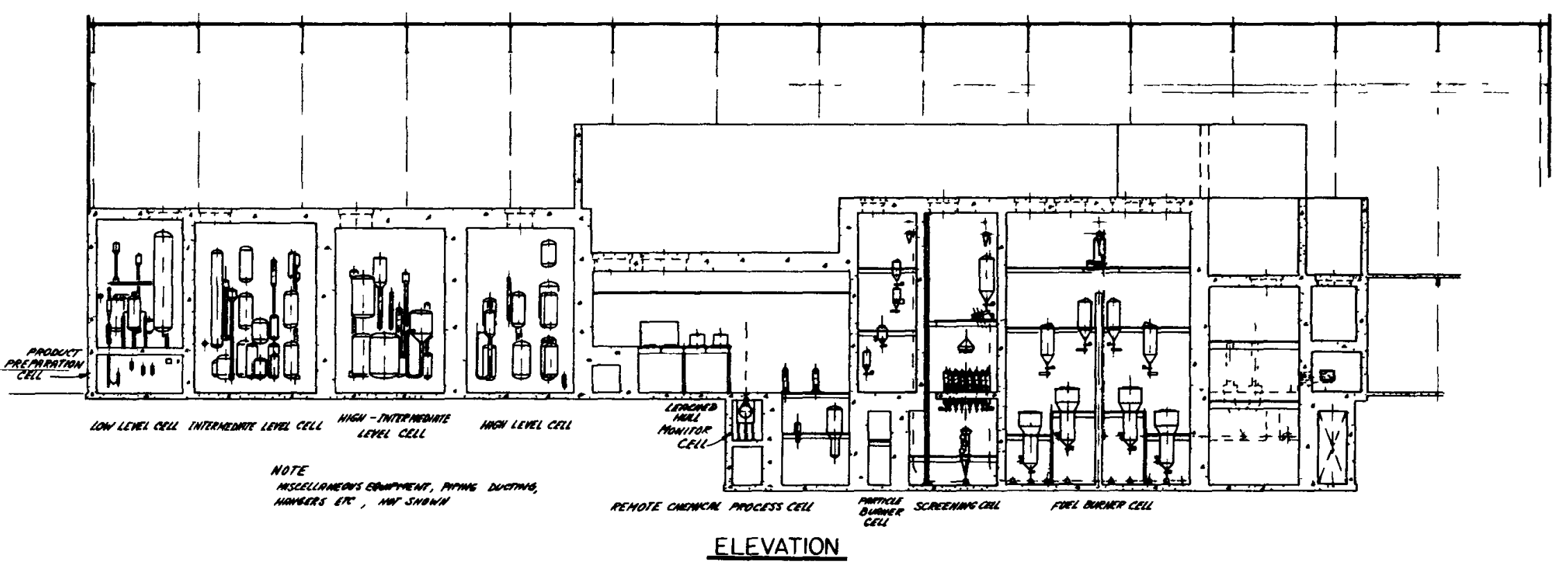

FIG. A-A PROCESS EQUIPMENT LAYOUT. 


\section{APPENDIX B}

ECONOMIC MODEL AND ASSUMPTIONS 
0 


\section{ECONOMIC MODEL AND ASSUMPTIONS}

The daily processing charge for the conceptual plant is calculated using a present worth analysis of the disbursements and receipts for the project considered in this study. The following economic model is used to determine the daily charge:

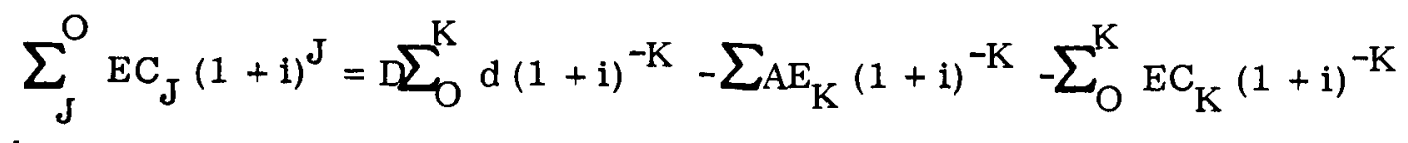
where

$$
\begin{aligned}
\mathrm{J} & =\text { number of years prior to startup } \\
\mathrm{K} & =\text { number of years after startup } \\
\mathrm{EC}_{\mathrm{J}} & =\text { equity capital expenditures in year } \mathrm{J} \\
\mathrm{D} & =\text { daily charge, } \$ / \text { day } \\
\mathrm{d} & =\text { processing days available for year } \mathrm{K} \\
\mathrm{AE} & =\text { annual expenses (interest, debt repayment, operating } \\
& \text { cost, local taxes, etc.) } \\
\mathrm{EC}_{\mathrm{K}} & =\text { equity capital expenditure in year } \mathrm{K} \\
(1+\mathrm{i}) & =\text { present worth factor for year } \mathrm{J} \\
(1+\mathrm{i}){ }^{-\mathrm{K}} & =\text { present worth factor for year } \mathrm{K} \\
\mathrm{I} & =\text { rate of return desired before income taxes } .
\end{aligned}
$$

Using the following economic and operating assumptions, the daily processing rate (D) for the plant is calculated to be $\$ 130,000 /$ day:

Economic Assumptions

(1) Debt to equity ratio -- $1 / 1$

(2) Annual return on equity -- 25 percent before taxes

(3) Interest rate on debt --8 percent per annum 
Operating Assumptions

(1) On-stream plan efficiency -- 250 days/yr ( 70\%)

(2) Attainment of full processing rate -- start of third processing year (1st year-half rate, 2nd year $-3 / 4$ rate)

(3) Years of plant operation -- 15 years.

Table B presents the cash flow worksheet used in determining the daily processing charge for the Conceptual HTGR Fuel Processing Plant. 


\section{-}

TABLE B

PRESENT YORTH ANALYSIS - DAILY RATE BASIS

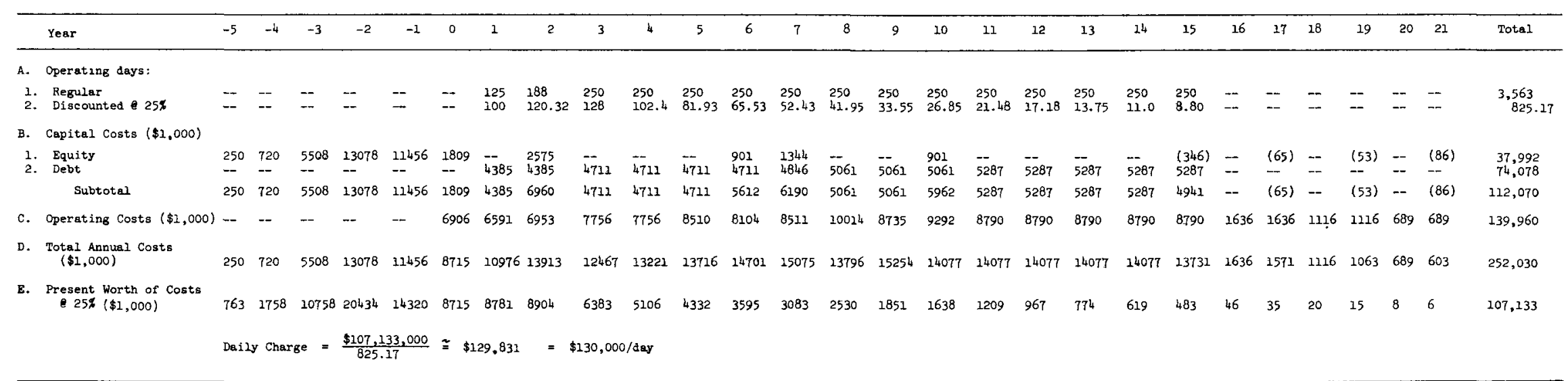


- 
APPENDIX C

CONCEPTUAL PLANT CAPITAL COSTS

49 
-

○ 


\section{APPENDIX $C$ \\ CONCEPTUAL PLANT CAPITAL COSTS}

A detailed breakdown of the conceptual plant capital costs is given in Table C. The Bechtel portion of the estimate includes all costs associated with the engineering and construction of the basic plant. Bechtel's estimate does not include land cost, process development, preliminary design and licensing, and other owner's costs, nor costs for a waste calcine canning and shipping facility and additional thorium storage tanks. These costs were estimated by Idaho Nuclear Corporation and are shown separately. 
I. DIRECT COSTS

A. Structures and Improvements

1. Site improvements

2. Main process building

a. Fuel storage

b. Headend cell(s)

(1) Fuel cutting

(2) Fuel crushing and burning

750

(3) Screening, particle crushing and burning

510

(4) Alumina recycle process

380

(5) Fissile particle storage

840

c. Solvent extraction cells

960

d. Product cell (U-233)

270

e. Waste disposal cell(s)

(1) Evaporation, calcination and ion exchange 320

(2) Offgas cleanup 180

f. Miscellaneous

270

3. Waste storage

a. Thorium storage vault

1,350

b. Aqueous storage vault

1,350

c. Calcine storage vault

270

330

4. Utilities building

520

5. Administrative building

6. Other

1,420

B. Process Equipment

1. Fuel un]oading and storage

- 440

2. Headend

a. Fuel cutting

b. Fuel crushing and burning

c. Screening

d. Alumina recycle process

520

e. Fissile particle handling

250

f. Fertile particle process

60

600

3. Solvent extraction (U-233)

a. H extraction cycle

b. Second extraction cycle

c. Third extraction cycle

4. Product (U-233)

5. Waste disposal equipment

a. Aqueous waste storage tanks

b. Evaporation, calcination and ion exchange

c. Calcined solids storage

1,010

450

620

40

1,410

1,280

890 
d. Offgas cleanup

e. Thorium storage tanks

f. Fissile particle storage (including containers)

6. Remote manipulators, shielded windows, and cranes

7. Chemical storage and makeup

C. Miscellaneous Equipment

1. Utilities

2. Services

3. Non-process

4,770

2,720

1,470

II. INDIRECT COSTS

A. Engineering Design and Inspection

B. Miscellaneous Construction

9,400

C. Contingency

7,700

D. Spare Parts

200

E. Installed Equipment Spares

100

Subtotal, Bechtel Estimated Capital Costs

IDAHO NUCLEAR ESTIMATE OF ADDITIONAL COSTS

I. DIRECT COSTS

A. Structures and Improvements

1. Calcine canning 280

2. Thorium storage vaults

3. Additional extraction system

B. Process Equipment

1. Calcine canning

2. Thorium storage tanks

3. Additional extraction system

1,000

C. Land and Land Rights

240

II. INDIRECT COSTS

A. General and Administrative

2,238

B. Engineering, Design, and Inspection 
C. Miscellaneous Construction$$
\text { Cost }
$$

$\underline{(\$ 1,000)}$

D. Contingency

E. Research and Development

1,097

F. Interest During Construction

1,000

4,900

G. Quality Assurance

1,940

H. Preliminary Design and Licensing

1,500

III. WORKING CAPITAL

1,100

Subtotal, Idaho Nuclear Estimated Additional Capital Costs \$22,031

Total Capital Costs for Conceptual Plant $\$ 82,031$ 
APPENDIX D

ESTIMATED MANPOWER AND SALARY

REQUIREMENTS FOR STAFFING THE CONCEPTUAL PLANT 
-

○ 


\section{APPENDIX D \\ ESTIMATED MANPOWER AND SALARY \\ REQUIREMENTS FOR STAFFING THE CONCEPTUAL PLANT}

Estimated manpower and salary requirements for staffing the conceptual plant are given in Table D. Salaries and wages are based on July 1969 rates; it is assumed that operating personnel would be experienced in chemical plant operations and licensed for nuclear fuel processing; also, key personnel and supervisors would have a background in radiochemical processing. 
TABLE D

CONCEPTUAL PLANT PERSONNEL

\begin{tabular}{|c|c|c|c|}
\hline Management & Number & $\begin{array}{c}\text { Salary and Wages } \\
(\$ / \mathrm{yr}) \\
\end{array}$ & $\begin{array}{r}\text { Total } \\
(\$ / y r) \\
\end{array}$ \\
\hline Plant Manager & 1 & 35,000 & 35,000 \\
\hline Assistant Plant Manager & 1 & 30,000 & 30,000 \\
\hline Production Superintendent & 1 & 25,000 & 25,000 \\
\hline Administrative Superintendent & 1 & 25,000 & 25,000 \\
\hline Technical Superintendent & 1 & 25,000 & 25,000 \\
\hline Secretary-Clerk-Typist & 5 & 5,000 & 25,000 \\
\hline Subtotal & 10 & & 165,000 \\
\hline \multicolumn{4}{|l|}{ Engineering } \\
\hline Supervisor & 1 & 20,000 & 20,000 \\
\hline Group Leader & 2 & 17,000 & 34,000 \\
\hline Design Engineer & 1 & 15,000 & 15,000 \\
\hline Process Engineer & 4 & 15,000 & 60,000 \\
\hline Instrument Engineer & 1 & 15,000 & 15,000 \\
\hline Mechanical Engineer & 1 & 15,000 & 15,000 \\
\hline Chemist & 2 & 12,000 & 24,000 \\
\hline Technician & 4 & 8,000 & 32,000 \\
\hline Draftsman & 2 & 8,000 & 16,000 \\
\hline Secretary-Clerk-Typist & 1 & 5,000 & 5,000 \\
\hline Subtotal & 19 & & 236,000 \\
\hline \multicolumn{4}{|l|}{ Production } \\
\hline Production Engineer & 2 & 12,000 & 24,000 \\
\hline Shift Supervisor & 5 & 14,000 & 70,000 \\
\hline Assistant Shift Supervisor & 5 & 12,000 & 60,000 \\
\hline Utility Foreman & 1 & 10,000 & 10,000 \\
\hline Operators & 76 & 8,500 & 646,000 \\
\hline Utility Operators & 9 & 9,000 & 81,000 \\
\hline Helpers & 24 & 7,000 & 168,000 \\
\hline Secretary-Clerk-Typist & 1 & 5,000 & 5,000 \\
\hline Subtotal & 123 & & $, 064,000$ \\
\hline
\end{tabular}




\begin{tabular}{|c|c|c|c|}
\hline Maintenance & Number & $\begin{array}{l}\text { Salary and Wages } \\
(\$ / \mathrm{yr}) \\
\end{array}$ & $\begin{array}{l}\text { Total } \\
(\$ / \mathrm{yr}) \\
\end{array}$ \\
\hline Supervisor & 1 & 17,000 & 17,000 \\
\hline Mechanical Engineer & 1 & 15,000 & 15,000 \\
\hline Electrical Engineer & 1 & 15,000 & 15,000 \\
\hline Foreman & 3 & 12,000 & 36,000 \\
\hline Coordinator & 1 & 12,000 & 12,000 \\
\hline Draftsman & 1 & 8,000 & 8,000 \\
\hline Tool Crib & 1 & 7,000 & 7,000 \\
\hline Electrician & 6 & 9,000 & 54,000 \\
\hline Instrumentation & 10 & 9,000 & 90,000 \\
\hline Mechanic & 6 & 9,000 & 54,000 \\
\hline Welder & 2 & 9,000 & 18,000 \\
\hline Insulator-Painter & 1 & 8,500 & 8,500 \\
\hline Sheet Metal-Carpenter & 1 & 8,500 & 8,500 \\
\hline Machinist & 1 & 9,000 & 9,000 \\
\hline Fitter & 6 & 8,500 & 51,000 \\
\hline Helpers & 6 & 7,500 & 45,000 \\
\hline Laundry & 2 & 7,000 & 14,000 \\
\hline Janitor & 4 & 6,000 & 24,000 \\
\hline Secretary-Clerk-Typist & 1 & 5,000 & 5,000 \\
\hline Subtotal & 55 & & 491,000 \\
\hline \multicolumn{4}{|l|}{ Health Physics/Safety } \\
\hline Supervisor & 1 & 14,000 & 14,000 \\
\hline Foreman & 1 & 12,000 & 12,000 \\
\hline H. P. Technician & 10 & 9,000 & 90,000 \\
\hline Safety Engineer & 1 & 12,000 & 12,000 \\
\hline Decontamination & 2 & 8,000 & 16,000 \\
\hline Issue Room & 1 & 7,000 & 7,000 \\
\hline Secretary-Clerk-Typist & $\underline{1}$ & 5,000 & 5,000 \\
\hline Subtotal & 17 & & 156,000 \\
\hline
\end{tabular}


TABLE D (contd.)

\begin{tabular}{|c|c|c|c|}
\hline Analytical Laboratory & Number & $\begin{array}{l}\text { Salary and Wages } \\
\begin{array}{c}(\$ / \mathrm{yr}) \\
\end{array}\end{array}$ & $\begin{array}{r}\text { Total } \\
(\$ / y r) \\
\end{array}$ \\
\hline Supervisor & 1 & 17,000 & 17,000 \\
\hline Group Leader & 2 & 15,000 & 30,000 \\
\hline Chemists & 7 & 12,000 & 84,000 \\
\hline Technicians & 21 & 8,000 & 168,000 \\
\hline Secretary-Clerk-Typist & 1 & 5,000 & 5,000 \\
\hline Subtotal & 32 & & 304,000 \\
\hline \multicolumn{4}{|l|}{ Support } \\
\hline Industrial Relations Supervisor & 1 & 20,000 & 20,000 \\
\hline Employment & 2 & 11,000 & 22,000 \\
\hline Records and Benefits & 1 & 11,000 & 11,000 \\
\hline Employee and Public Relations & 1 & 15,000 & 15,000 \\
\hline Materiel Supervisor & 1 & 20,000 & 20,000 \\
\hline Purchasing/Contracts & 2 & 11,000 & 22,000 \\
\hline Receiving/Expediting & 2 & 11,000 & 22,000 \\
\hline Stores and Delivery & 2 & 11,000 & 22,000 \\
\hline Special Services & 1 & 11,000 & 11,000 \\
\hline Security & 9 & 6,000 & 54,000 \\
\hline Nurse & 1 & 7,000 & 7,000 \\
\hline Doctor (Part Time) & 1 & 5,000 & 5,000 \\
\hline Accountability & 1 & 25,000 & 15,000 \\
\hline Accounting Supervisor & 1 & 20,000 & 20,000 \\
\hline Finance & 1 & 12,000 & 12,000 \\
\hline Plant and Equipment Records & 1 & 11,000 & 11,000 \\
\hline Budget and Cost Control & 2 & 11,000 & 22,000 \\
\hline General Accounting & 2 & 11,000 & 22,000 \\
\hline Payroll Clerks & 3 & 8,000 & 24,000 \\
\hline Secretary-Clerk-Typist & 14 & 5,000 & 70,000 \\
\hline Subtotal & 49 & & 427,000 \\
\hline Total & 305 & & $2,843,000$ \\
\hline
\end{tabular}


APPENDIX E

ESTIMATED CHEMICAL REQUIREMENTS FOR THE CONCEPTUAL PLANT 
0 


\section{APPENDIX E}

\section{ESTIMATED CHEMICAL REQUIREMENTS FOR THE CONCEPTUAL PLANT}

The chemical requirements of the process are given in Table $E$. The annual consumption was determined by flowsheet requirements; the unit costs were obtained from the Oil, Paint, and Drug Reporter [17] with the exception of the alumina unit cost. The cost of high-grade, sized alumina was based on actual charges incurred at the NRTS for this material.

\section{$\underline{\text { TABLE E }}$}

CHEMICAL REQUIREMENTS OF THE CONCEPTUAL PLANT

\begin{tabular}{|c|c|c|c|}
\hline Chemical & Annual Consumption & $\begin{array}{l}\text { Unit Cost } \\
(\$) \\
\end{array}$ & $\begin{array}{c}\text { Annual Cost } \\
(\$)\end{array}$ \\
\hline $\mathrm{A}_{2} \mathrm{O}_{3}$ & $3.48 \times 10^{5} \mathrm{Ib}$ & $.688 / 1 \mathrm{~b}$ & 239,424 \\
\hline $\mathrm{HNO}_{3}$ & $1.27 \times 10^{6} \mathrm{Ib}$ & $.054 / 2 b$ & 68,580 \\
\hline $\mathrm{HF}$ & $1.92 \times 10^{3} \mathrm{lb}$ & $.355 / 1 b$ & 682 \\
\hline $\mathrm{Cd}\left(\mathrm{NO}_{3}\right)_{2}$ & $4.32 \times 10^{4} \mathrm{Ib}$ & $1.445 / 1 \mathrm{~b}$ & 62,424 \\
\hline $\mathrm{NaHSO}_{3}$ & $8.49 \times 10^{3} 1 \mathrm{~b}$ & $.04 / 1 b$ & 340 \\
\hline $\mathrm{Na}_{2} \mathrm{~B}_{4} \mathrm{O}_{7}$ & $3.29 \times 10^{2} 1 b$ & $.027 / 1 \mathrm{~b}$ & 9 \\
\hline $\mathrm{Ca}\left(\mathrm{NO}_{3}\right)_{2}$ & $9.95 \times 10^{3} 1 \mathrm{~b}$ & $.30 / 1 b$ & 2,985 \\
\hline $\mathrm{Fe}\left(\mathrm{NH}_{2} \mathrm{SO}_{3}\right)_{2}$ & $4.01 \times 10^{3} 1 \mathrm{~b}$ & $.31 / 1 b$ & 1,243 \\
\hline $\mathrm{H}_{3} \mathrm{PO}_{4}$ & $1.59 \times 10^{3} \mathrm{Ib}$ & $.069 / 1 \mathrm{~b}$ & 110 \\
\hline $\mathrm{Na}_{2} \mathrm{CO}_{3}$ & $4.25 \times 10^{4} 1 \mathrm{~b}$ & $.025 / 1 b$ & 1,062 \\
\hline $\mathrm{NaOH}$ & $3.37 \times 10^{4} 1 \mathrm{~b}$ & $.0535 / 1 b$ & 1,803 \\
\hline TBP & $1.18 \times 10^{5} 1 \mathrm{~b}$ & $.525 / 1 b$ & 61,950 \\
\hline Amsco & $5.12 \times 10^{4} \mathrm{gal}$ & $.637 / \mathrm{gal}$ & 32,614 \\
\hline Kerosene & $5.61 \times 10^{4} \mathrm{gal}$ & $.16 / \mathrm{gal}$ & 8,976 \\
\hline & & Subtotal & 482,202 \\
\hline \multicolumn{3}{|c|}{ Contingency $(10 \%)$} & 48,220 \\
\hline & & Total & 530,422 \\
\hline
\end{tabular}


-

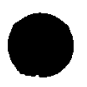




\section{APPENDIX F}

ESTIMATED SOLID WASTE DISPOSAL COSTS 
0

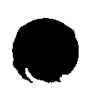




\section{APPENDIX F \\ ESTIMATED SOLID WASTE DISPOSAL COSTS}

The annual costs for disposal of solid waste at a Federal Repository are given in Table $\mathrm{F}$. These include the solids containers costs, shipping costs, and repository costs, but do not include calcination or on-site storage costs, which are included in plant costs.

\section{$\underline{\text { TABLE F }}$}

ANNUAL SOLID WASTE DISPOSAL COSTS

Calcined Waste Disposal

Containers (141@ @1440 ea)

Shipping ${ }^{[a]}$ (36@ \$4080/shipment)

Repository costs (141 @ \$504 ea)

$$
\begin{array}{r}
\$ 203,000 \\
147,000 \\
71,000 \\
\hline \$ 421,000
\end{array}
$$

Fissile Particle Disposal

Containers (822@\$700 ea)

Shipping $^{[a]}$ (30@\$4080/shipment)

Repository costs (822 @ \$300 ea)

Total
$\$ 575,000$

122,000

247,000

$\$ 944,000$

[a] Based on 1500 miles per shipment. 